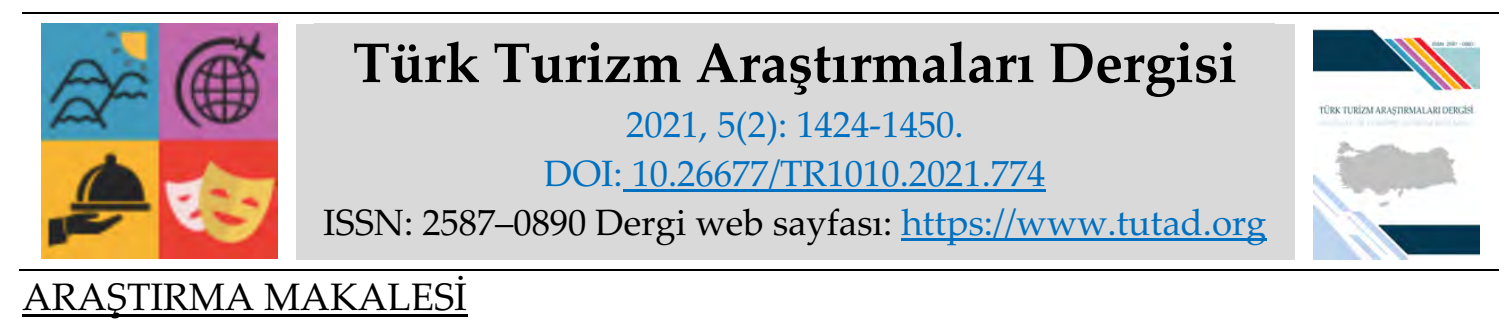

\title{
Sosyal Sorumluluk Uygulamalarının Çalışanların Örgütsel Bağlılıklarına Etkisi Üzerine Bir Araştırma: Otel İşletmelerinde Bir Uygulama*
}

Dr. Öğr. Üyesi Hümeyra TÖRE BAŞAT, Afyon Kocatepe Üniversitesi, Afyon Meslek Yüksekokulu, Afyonkarahisar, e-posta: humeyratore@gmail.com ORCID: https://orcid.org/0000-0003-4064-492X

Dilek PEKMEZCI, Yüksek Lisans Öğrencisi, Afyon Kocatepe Üniversitesi, Sosyal Bilimler Enstitüsü, Afyonkarahisar, e-posta: pekmezci dilek@hotmail.com

ORCID: https://orcid.org/0000-0001-6341-2916

Öz

Ekonomik bir kuruluş olmalarının yanı sıra sosyal bir kuruluş olma misyonu da taşıyan işletmelerin günümüz koşullarında faaliyetlerine kesintisiz ve rekabet avantajı sağlayarak devam edebilmeleri için sosyal sorumluluk faaliyetlerinde aktif olarak rol almaları gerekmektedir. İşletmeler, sosyal anlamda tüketicilere, topluma, çevreye, devlete, tedarikçilere oldukları kadar iç müşterileri olan çalışanlarına karşı da sorumludurlar. Özellikle turizm gibi emeğin yoğun olduğu sektörlerde, çalışanlar işletmelerinin en önemli sermayesi olarak görülmektedir. Bu doğrultuda çalı̧manın amacı, İstanbul'da faaliyet gösteren uluslararası zincir otel işletmelerinde sosyal sorumluluk uygulamalarının çalışanların örgütsel bağllıklarına etkisini belirlemektir. Araştırma kapsamında İstanbul'da faaliyet gösteren beş yıldızlı üç uluslararası zincir otel işletmesine bağlı üçer otel olmak üzere toplam dokuz otelin çalışanları araştırmanın evrenini oluşturmakta olup, örneklem grubu ise 352 çalışanı içermektedir. Anket tekniği ile elde edilen verilerin analizinde betimsel istatistiklerin (yüzde, frekans, aritmetik ortalama, standart sapma vb.) yanısıra $\mathrm{t}$ testi, varyans analizi ve korelasyon analizi kullanılmıştır. Araştırma sonucunda, otel işletmelerinin sosyal sorumluluk uygulama düzeylerinin yüksek olduğu tespit edilirken, çalışanların örgütsel bağlllık düzeylerinin orta olduğu belirlenmiştir. Ayrıca; otel işletmelerinde sosyal sorumluluk uygulamalarının ekonomik sorumluluk boyutunda yoğunlaştığı, etik sorumluluklar boyutuna ise daha az odaklandıkları görülmektedir. Bununla birlikte çalışanların duygusal bağlllıklarının oldukça güçlü olduğu, devam ve normatif bağlllıklarının ise buna göre daha düşük olduğu anlaşılmaktadır.

*Bu çalışma, Dilek PEKMEZCI'nin “Sosyal Sorumluluk Uygulamaları ile Çalışanların Örgütsel Bağlllık ve İş Performansları Üzerine Bir Araştırma: Otel İşletmelerinde Bir uygulama" adlı yüksek lisans tezinden üretilmiştir.

Anahtar Kelimeler: Sosyal Sorumluluk, Örgütsel Bağllılı, Otel Çalışanları, Otel İşletmeleri, İstanbul.

Makale Gönderme Tarihi: 18.02 .2021

Makale Kabul Tarihi: 03.06.2021

\section{Önerilen Atıf:}

Töre Başat, H. ve Pekmezci, D. (2021). Sosyal Sorumluluk Uygulamalarının Çalışanların Örgütsel Bağlılıklarına Etkisi Üzerine Bir Araştırma: Otel İşletmelerinde Bir Uygulama, Türk Turizm Araştırmaları Dergisi, 5(2): 1424-1450.

๑ 2021 Türk Turizm Araştırmaları Dergisi. 


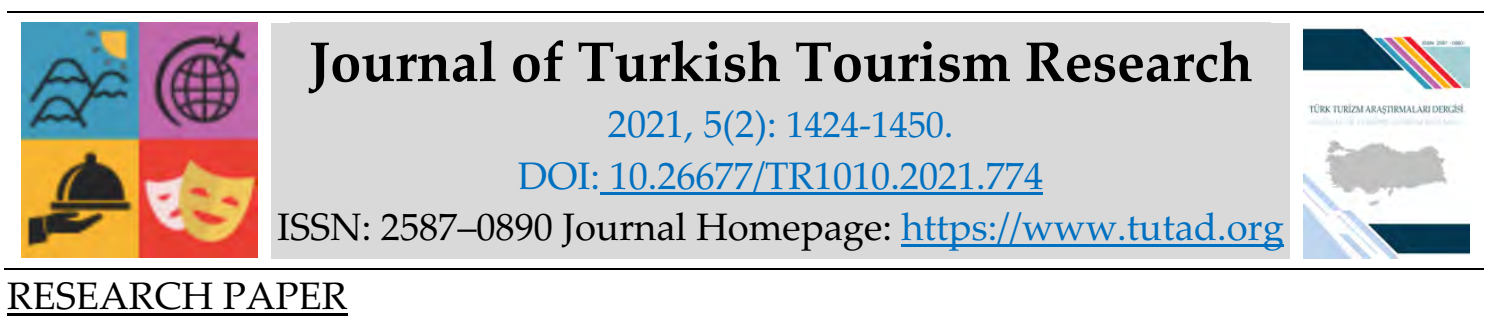

\title{
A Research on The Effect of Social Responsibility Practices on Employees' Organizational Commitment: An Application in Hotel Enterprises
}

Assistant Prof. Dr. Hümeyra TÖRE BAŞAT, Afyon Kocatepe University, Afyon Vocational School, Afyonkarahisar, e-mail: humeyratore@gmail.com

ORCID: https://orcid.org/0000-0003-4064-492X

Dilek PEKMEZCI, MSc. Student, Afyon Kocatepe University, Social Sciences Institute, Afyonkarahisar, e-mail: pekmezci_dilek@hotmail.com

ORCID: https://orcid.org/0000-0001-6341-2916

\begin{abstract}
In addition to being an economic organization, the enterprises which have the mission of being a social institution should take an active role in their social responsibility practices in order to continue their activities in a sustainable way with a competition advantage. Enterprises are also socially responsible for their employees as well as to the public, consumers, the environment, the government and the suppliers. Employees are seen as most important capital of enterprises especially in sectors such as tourism, where employees give intense services. The aim of this study is to determine the effects of social responsibility practices on the level of employees' organizational commitment at international chains hotel enterprises in Istanbul. For this purpose, the employees of nine hotels, which are affiliated to three international five-star hotels in Istanbul, constitute the population of the research and the sample group includes 352 employees. Frequency and percentage, arithmetic mean values, standard deviation, t-test, analysis of variance and correlation analysis were used for the analysis of the data obtained via the survey in this research. As a result of the research, it was determined that the social responsibility practices levels of the hotel enterprises were high, the organizational commitment levels of the employees were medium. The findings obtained from the research were evaluated and interpreted and suggestions regarding the subject were developed. Also; It is observed that social responsibility practices in hotel businesses concentrate on the dimension of economic responsibility, while they focus less on the dimension of ethical responsibilities. However, it is understood that the emotional commitment of the employees is quite strong, and their continuance and normative commitment is lower than this.
\end{abstract}

Keywords: Social Responsibility, Organizational Commitment, Hotel Employees, Hotel Enterprises, İstanbul.

Received: 18.02 .2021

Accepted: 03.06.2021

\section{Suggested Citation:}

Töre Başat, H. and Pekmezci, D. (2021). A Research on The Effect of Social Responsibility Practices on Employees' Organizational Commitment: An Application in Hotel Enterprises, Journal of Turkish Tourism Research, 5(2): 1424-1450.

(C) 2021 Türk Turizm Araştırmaları Dergisi. 


\section{Gíriş}

Modern iş hayatındaki işletmelerin, faaliyet gösterdikleri alanlarda, başta çalışanları olmak üzere tüketiciler, toplum, çevre, devlet, tedarikçiler gibi tüm paydaşları ile sürekli iletişim ve etkileşim içerisinde bulunarak varlıklarını kesintisiz olarak sürdürebilecekleri düşünülmektedir. Küreselleşmenin ve teknolojinin gelişmesi ile bireylerin her türlü bilgiye kolaylıkla ulaşabilmesi toplumsal olaylar karşısındaki farkındalıklarını arttırmakta ve işletmelerden olan beklentilerine de yeni boyutlar kazandırmaktadır. Artan farkındalıkla birlikte, işletmeler mal ve hizmet üreten ticari kuruluşlar olmanın yanı sıra sosyal birer varlık olarak algılanmaya başlanmış ve işletmelerin buna uygun sorumlu davranışlarda bulunması beklenir olmuştur. Bu beklenti sonucu varlığını başarılı bir şekilde devam ettirmek isteyen işletmeler buna uygun faaliyetlerde bulunmak zorunda kalmışlar ve bu da sosyal sorumluluk kavramını işletmelerin gündemine taşımıştır. Tüketiciler aynı mal ve hizmeti üreten işletmelerden birini tercih etmeleri söz konusu olduğunda sosyal sorumluluk faaliyetlerinde aktif olanlara öncelik vermektedirler. Hatta bunun için daha fazla ödemeyi bile kabul etmektedirler. Doğal güzellikler ve kültürel zenginlikler gibi kıt kaynaklardan faydalanan turizm sektörünün ise sürdürülebilirliğini devam ettirebilmesi için sosyal sorumluluk faaliyetlerine daha fazla değer vermesi gerekmektedir. Turizm aktivitelerinden en çok etkilenenlerin başında turizm işletmelerinin içerisinde faaliyet gösterdikleri doğal çevre ve yerel toplum gelmektedir. Ayrıca emeğin yoğun olduğu bir sektör olması çalışanları da oldukça önemli hale getirmektedir. Son tüketici ile birebir iletişim halinde olan, işletmeyi temsil eden kişiler bizzat çalışanlardır ve işletmesinden memnun olan bir çalışanın tüketiciyi memnun edememesi neredeyse imkansızdır. Çalıştı̆̆ işletme tarafından temel ihtiyaçlarının karşılanmasının yanı sıra, bireysel olarak önemsenen ve değer verilen çalışanların işletmeye karşı olan bağlılıkları ve performansları da pozitif yönde artacak ve bu da tüketici memnuniyeti olarak işletmeye geri dönüş sağlayacaktır.

Hizmet sunan turizm işletmelerinde hizmetin sunumunda müşterilerle birebir iletişim halinde olan, işletmeyi temsil eden ve müşterilerin işletmeyi tekrar tercih etmelerinde etkili olan kişiler çalışanlardır. Dolayısı ile dış müşterilerini memnun etmek isteyen işletmelerin öncelikle iç müşterileri olan çalışanlarını memnun etmeleri daha uygun görünmektedir (Avcı ve Küçükusta, 2009: 33). Ancak turizm sektöründeki uzun ve düzensiz çalışma saatleri, izinsiz çalışma vb. ağır çalışma koşullarından dolayı kalifiye ve profesyonel çalışanları işletmede tutmak gün geçtikçe zorlaşmaktadır (Çuhadar ve Gencer, 2016: 1325). Çalışanların rekabet avantajı sağlamadaki öneminin farkında olan işletmelerin bu olumsuz durumları tolere etmek, çalışanlarının örgüte bağlılığını ve dolayısıyla performansını arttırmak amacı ile temel ihtiyaçlarını (maaş, sigorta vb.) karşılamalarının yanı sıra onları önemsediklerini de gösterecek sosyal uygulamalarda bulunmaları beklenmektedir (Akova ve Bayhan, 2015: 802). Ayrıca işletmelerin dış paydaşları (toplum, tüketiciler, devlet vb.) üzerinde yarattığı olumlu imajda çalışanların işletmeye olan bağlılığını ve performansını pozitif yönde etkilemektedir (Kesen ve Sipahi, 2016: 1927). İşletmelerin olumlu imaj yaratmasında ise sosyal sorumluluk uygulamaları pozitif yönde katkıda bulunabilecektir.

Bu bağlamda hazırlanan çalışmanın birincil amacı, turizm sektöründe faaliyet gösteren otel işletmelerinde sosyal sorumluluk uygulamalarının çalışanların örgütsel bağlılıklarına etkisi üzerine bir araştırma yapmaktır. Amacın gerçekleşmesi için beş yıldızlı uluslararası zincir oteller üzerinde araştırma gerçekleştirilmiştir. Sosyal sorumluluk projeleri ile çalışanların örgütsel bağlılık değişkenleri arasında anlamlı bir ilişki olup olmadığını belirlemek, çalışmanın öncelikli amaçları arasında yer almaktadır. 


\section{KAVRAMSAL ÇERÇEVE}

İşletmelerin sürdürülebilirliğini başarıyla gerçekleştirmesinde önemi gün geçtikçe artan sosyal sorumluluk kavramı ilk defa Oliver Sheldon'un (1923) "Yönetim Felsefesi" adlı kitabındaki "İşletmenin yönetim prensipleri, toplumun sosyal faydası üzerinde odaklanmalıdır." ifadesi ile gündeme gelmiştir. Sosyal sorumluluk kavramı Holme ve Watts (2000) tarafından, işletmelerin ekonomik gelişimin yanı sıra toplumun ve işletme çalışanlarının ve ailelerinin yaşam kalitesini iyileştirmek adına üstlendikleri daimi yükümlülük olarak ifade edilmiştir.

Newsom vd., (2000: 224), iyi vatandaşlı̆̆ın bir diğer terimi olarak nitelendirdikleri sosyal sorumluluğu, çevreye zarar vermeyen ve toplumun sosyal, politik ve ekonomik gelişimine olumlu katkıda bulunan ürünler üretmek/hizmetler sunmak ve çalışanlara adil ve eşit davranmak, ayrımcılık yapmamak ve hak ettikleri ücretleri ödemek şeklinde tanımlarken, Mohr vd., (2001: 47) ise "bir şirketin herhangi bir zararlı etkiyi en aza indirgemek veya ortadan kaldırmak ve toplum üzerindeki uzun vadeli yararlı etkisini en üst düzeye çıkarma taahhüdü” olarak tanımlamışlardır.

Toplumun değer yargılarıyla yakından ilişkili olan sosyal sorumluluk kavramı çok fazla değişkenlik göstermektedir. Toplumdan topluma ve zamandan zamana değişen bu kavramın, konu ve sınırlarını tam olarak belirlemek, açık, net ve tam bir şekilde ortaya koymak oldukça güçtür (Bayrak, 2001: 96). Buna rağmen Carroll (1991: 4) sosyal sorumluluk uygulamalarını ekonomik, yasal, etik ve gönüllü sorumluluklar olmak üzere dört boyutlu bir piramit olarak ele almış ve piramitteki sıralamayı da sorumlulukların önem derecelerine göre belirlemiştir.

İşletmelerin karlı bir şekilde varlığını sürdürebilmesi ekonomik sorumluluklarını yerine getirmesine bağlı olduğundan piramidin birinci basamağında ekonomik sorumluluklar yer almaktadır. Ancak karlılı̆̆ını sürdürmek için ekonomik sorumluluklarını uygularken yasaları ihlal etmemek adına yasal sorumluluklarını da yerine getirmelidir çünkü toplumun kabul edeceği ve etmeyeceği davranışlar yasalar tarafından belirlenmiştir. Yasalarla belirlenmeyen ancak toplumun işletmelerden uymasını istediği diğer davranışlarda ahlaki sorumluluklar olarak piramidin üçüncü basamağında yer almaktadır. Dördüncü basamakta ise işletmelerin hem iç hem de dış sosyal paydaşlarına katkıda bulunmalarını ve yaşam kalitesini iyileştirme çabalarını ifade eden gönüllü sorumluluklar yer almaktadır (Carroll, 1991: 4). Ekonomik ve yasal sorumluluklar sosyal olarak istenen, etik sorumluluklar sosyal olarak umut edilen ve beklenen, gönüllü sorumluluklar ise arzu edilendir (Windsor, 2001: 230).

Emek yoğun bir sektör olan turizm sektöründe, otel yönetimi kurumsal sosyal sorumluluk uygulamalarında çalışanını göz önünde bulundurmalıdır. Özellikle, çalışanın iş güvenliğinin sağlanması, özel yaşamına saygı, liyakat ilkesinin uygulanması, aile yaşamına saygı, iş yaşamında tatmin olması için önlemler almalıdır (Çalışkan ve Ünüsan, 2011: 155). İnsan ile insana hizmetin sunulduğu turizm sektöründe kaliteli bir hizmetin sunulabilmesi ancak yetenekli ve kalifiye çalışanlar ile mümkündür (Özdemir ve Akpınar, 2002: 85). İşletme performansını arttıran ve yöneten önemli bir güç olan çalışanların elde tutulamaması ise iş kaybı yaratacağı gibi maliyetlerin artmasına da sebep olacaktır (Altınöz, 2018: 88). Bunun önüne geçebilmek için ise işletmelerin çalışanlarına karşı yasal sorumluluklarının yanı sıra sosyal sorumluluklarını da yerine getirmeleri ve çalışanlarının kendileri için değerli olduklarını hissettirmeleri gerekmektedir. Çünkü işletmeleri tarafından değerli olduğunu bilen çalışanlar kendilerini işletmelerine daha bağlı hissedeceklerdir (Cappelli, 2000).

Turizm işletmelerinin çalışanlarına karşı olan sorumluluklarını adil ücret sisteminin varlığı, uygun çalışma koşullarının ve ortamının yaratılması, iş güvenliği ve işçi sağlığına yönelik önlemler alınması, çalışanların haklarına saygı gösterme ve işletme kararlarına katılımını sağlama, çalışanlara özgürce konuşma hakkı verme, kreş imkanı sunma, esnek çalışma 
saatlerinin düzenlenmesi, yıllık izinlerin düzenlenmesinde çalışanların ihtiyaç ve isteklerinin de dikkate alınması, çalışanların iş stresinden uzaklaşmasını ve motivasyonunu sağlamak için gezi, piknik, eğlence, balo vb. gibi etkinliklerin düzenlenmesi, çalışanların sendika kurma ve grev yapma hakkına saygı duyulması, çalışanlar arasında ayrımcılık yapılmaması ve cinsel tacizden korunması, hizmetiçi eğitim verilmesi ve adil terfi imkanının sunulması şeklinde özetlemek mümkündür (Şimşek, 1999; Çolakoğlu, 2005: 68; Boylu vd., 2007: 33; Ateşoğlu ve Türker, 2010: 212; Pelit ve Pekmezci, 2012: 330-331).

Örgütsel bağlllık kavramı, ilk kez 1956 yılında Whyte tarafından kullanılmıştır (Örücü ve Kışlalığlu, 2014: 46). “Örgütsel bağlllık, örgüt için yüksek çaba harcama arzusu içerisinde olup örgütün bir üyesi olarak kalma isteği ve örgütün amaç ve değerlerine olan inanç unsurlarından oluşan bir bütündür" (Naktiyok ve İşcan, 2014: 23). Başka bir tanımda örgütsel bağl1lık kavramı şu şekilde açıklanmaktadır: "Örgütsel bağlılık; çalışanın örgütün önemli bir elemanı olabilmek için çabalaması, örgüt amaçlarını kendi amaçları gibi görmesi, çalışanın örgütü bir aile ve kendisini de bu ailenin bir ferdi olarak görmesidir" (Taşkın ve Yeni, 2016: 65). Örgütsel bağlllık kavramından söz edilebilmesi adına örgütsel amaçların benimsenmesi, örgütün hedeflerine bağlı kalınması, örgütte kalmaya yönelik istek duyulması, örgütün amaç ve hedeflerinden etkilenilmesi, örgütsel çıkarların kişisel çıkarların önünde tutulması gibi hususların varlığ gerekmektedir (Liou, 2008: 120; Demirel, 2009: 117).

Allen ve Meyer yaklaşımı, örgütsel bağlılıkla ilgili yaklaşımlar arasında en çok kabul edileni olarak bilinmektedir. Öyle ki bugün örgütsel bağlllıkla ilgili yapılan birçok araştırmada Allen ve Meyer'in geliştirdiği ölçek kullanılmaktadır. Allen ve Meyer yaklaşımına göre örgütsel bağlılık üç temel boyuttan meydana gelmektedir. Bu üç boyut; duygusal bağlllık, devam bağlılığı, normatif bağlılık şeklinde sıralanmaktadır (Gül, 2002: 45). Örgütsel bağlılık yaklaşımlarından Allen ve Meyer yaklaşımının içeriği Tablo 1'de gösterildiği gibidir.

Tablo 1. Allen ve Meyer Yaklaşımı

\begin{tabular}{|c|l|l|}
\hline \multicolumn{1}{|c|}{ BAĞLILIK } & \multicolumn{1}{|c|}{ GEREKÇE } & \multicolumn{1}{|c|}{ TANIM } \\
\hline Duygusal Bağglılı & Çalışanın bunu istemesi & $\begin{array}{l}\text { Çalışanın örgüte duygusal tutkunluğu, } \\
\text { örgütle özdeşleşmesi ve örgüte } \\
\text { katılımda bulunması }\end{array}$ \\
\hline Devamlılık Bağlllığı & $\begin{array}{l}\text { Çalışanın buna zorunlu } \\
\text { olması }\end{array}$ & $\begin{array}{l}\text { Çalışanın işten ayrılması durumunda } \\
\text { karşılaşacağı maliyetlerin farkındalığ1 }\end{array}$ \\
\hline Normatif Bağlılık & $\begin{array}{l}\text { Çalışanın bunu doğru } \\
\text { bulması }\end{array}$ & $\begin{array}{l}\text { Çalışanın örgütsel üyeliğinin } \\
\text { sürdürülmesi yönünde hissettiği } \\
\text { yükümlülük }\end{array}$ \\
\hline
\end{tabular}

Kaynak: Arbak ve Kesken, 2005: 67-68; Çelebi, 2009: 119.

\section{YÖNTEM}

\section{Araştırmanın Amacı, Önemi ve Araştırma Soruları}

Betimsel bir nitelik taşıyan bu araştırmada, beş yıldızlı otel işletmelerinde sosyal sorumluluk uygulamalarının çalışanların örgütsel bağlllıklarına etkisinin belirlenmesi amaçlanmıştır. Bu temel amaç çerçevesinde araştırmada aşağıdaki sorulara cevap aranmıştır:

1. Çalışanların otel işletmelerinin sosyal sorumluluk uygulamalarına yönelik görüşleri nelerdir? 
2. Beş yıldızlı otel işletmesi çalışanlarının örgütsel bağlılık düzeyleri nedir?

3. Çalışanların otel işletmelerinin sosyal sorumluluk uygulamalarına yönelik görüşleri demografik özelliklerine göre anlamlı bir farklılık göstermekte midir?

4. Beş yıldızlı otel işletmesi çalışanlarının örgütsel bağlılık düzeyleri demografik özelliklerine göre anlamlı bir farklılık göstermekte midir?

5. Sosyal sorumluluk uygulamaları ve örgütsel bağlılık arasında anlamlı bir ilişki var mıdır?

Bu çalışmada, turizm sektöründeki işletmelerin kaliteli ve sürdürülebilir bir şekilde faaliyetlerine devam edebilmesi için önemli bir kaynak olan çalışanlar üzerinde konuyla ilgili bir uygulama gerçekleştirilerek sonuçlar karşılaştırılmıştır. Böylelikle otel işletmelerindeki sosyal sorumluluk uygulamaları ile çalışanların örgütsel bağlılığı arasındaki ilişkiye yönelik mevcut durumun ortaya konulması, otel işletmelerinde sosyal sorumluluk uygulamalarının alanında uzman, eğitimli, gerekli bilgi, beceri ve tecrübeye sahip çalışanları istihdam edebilmesi, mevcut çalışanları işletmeye bağlı ve iş performansı yüksek hale getirebilmesi için politikalar geliştirilebilmesi amacıyla ilgili literatüre katkı sağlaması bakımından önemlidir.

\section{Veri Toplama Yöntemi}

Bu çalışmada veri toplama yöntemi olarak anket kullanılmıştır. Söz konusu anket temel olarak üç bölümden oluşmaktadır. Anketin birinci bölümünde çalışanların demografik özelliklerini belirlemeye yönelik 7 adet soruya (cinsiyet, medeni durum, yaş, eğitim durumu, çalışılan departman, şu anki çalıştı̆̆ işletmedeki ve sektördeki çalışma süresi ve aylık geliri) yer verilmiştir. İkinci bölümde, çalışanların beş yıldızlı otel işletmelerindeki sosyal sorumluluk uygulamalarına yönelik görüşlerini belirlemek üzere Maignan ve Ferrell (2001) tarafından geliştirilen Çalışkan (2010) tarafından kullanılan 26 madde ve 4 boyuttan (etik, gönüllülük, yasal ve ekonomik) oluşan "sosyal sorumluluk uygulama ölçeği" yer almaktadır. Anketin üçüncü bölümünde, çalışanların örgütsel bağlılık düzeylerini belirlemek üzere Allen ve Meyer (1990) tarafından geliştirilen 18 madde ve 3 boyuttan (duygusal, normatif ve devam) oluşan "örgütsel bağlllık ölçeği" yer almaktadır.

\section{Evren ve Örneklem}

$\mathrm{Bu}$ araştırmanın evreni İstanbul'da faaliyet gösteren uluslararası beş yıldızlı zincir otel işletmelerinin çalışanlarından oluşmaktadır. Çalışmada zaman, maliyet ve ulaşılabilirlik kısıtlarından dolayı örneklem alınma yoluna gidilmiş olup uygulamayı kabul eden 3 zincir otel işletmesinde her bir departmanı temsil etmesi açısından "tabakalı örnekleme yöntemi" ile örneklem seçilmiştir. Bu doğrultuda uluslararası beş yıldızlı 3 zincir otel işletmesinin 3'er otelinde olmak üzere 9 otel işletmesinde anket uygulaması gerçekleştirilmiştir.

Çalışmada örneklem büyüklüğünün belirlenmesi için Sekaran (2003) ve Özdamar (2001) tarafından nicel araştırmalar için önerilen $n=\mathrm{s}^{2} Z \alpha^{2} / \mathrm{d}^{2}$ formülünden yararlanılmıştır. Buna göre 40 kişilik pilot uygulama sonucunda standart sapma değeri $\mathrm{s}=0,9 ; 0,05$ anlamlılık düzeyine karşılık gelen teorik değer $Z_{0,05}=1,96$ ve örneklem hatasını ortaya koyan etki büyüklüğü (effect size) $d=0,1$ olarak alınmış olup, formülde yerine konulduğunda minimum örneklem büyüklügü 312 olarak hesaplanmıştır. Bu çerçevede 400 adet anket çoğaltılmış, ilgili işletmelerde uygulanmış ve eksik, hatalı vb. veriler dikkate alınarak 352 adet anket değerlendirilmeye alınmıştır. 


\section{Veri Analiz Yöntemi}

Çalışmada elde edilen verilerin analizleri için SPSS paket programı kullanılmıştır. Buna göre, çalışanların demografik özellikleri frekans ve yüzde dağılımları ile sunulmuştur. Bununla birlikte otel çalışanlarının sosyal sorumluluk uygulamalarına yönelik görüşleri ile örgütsel bağlılık düzeyleri frekans ve yüzde dağılımlarının yanısıra aritmetik ortalama ve standart sapma değerleri ile betimlenmiştir. Diğer taraftan, çalışanların sosyal sorumluluk uygulamalarına yönelik görüşleri ile örgütsel bağlılık ve iş performans düzeylerinin demografik özelliklerine göre karşılaştırılması ise parametrik test varsayımları gerçekleştiği için iki grup için bağımsız örneklemler t-testi (independent samples t-test), üç ve daha fazla grup için tek yönlü varyans analizi (one way ANOVA) ile yapılmıştır. Varyans analizi sonucunda grupların ikili karşılaştırılmasında çoklu karşılaştırma testlerinden Tukey testi uygulanmıştır. Analizlerin uygulanmasında her bir gruptaki birey sayısının 10'un altında olması durumunda birleştirme yapılmıştır. Ayrıca sosyal sorumluluk uygulamaları ve örgütsel bağlılık arasındaki ilişkiler Pearson korelasyon analizi ile belirlenmiştir. Bunula birlikte ölçeklerin yapı geçerliği için faktör analizi uygulanmış olup, güvenirlik için ise Cronbach's Alpha değerleri hesaplanmıştır.

\section{BULGULAR}

Araştırmaya katılan toplam 352 katılımcının \%58,2'si erkek, \%41,8'i kadındır. Katılımcıların $\% 53,7^{\prime}$ si bekar, $\% 46,3^{\prime}$ ü evlidir. Çalışanların yaş grupları incelendiğinde $\% 41,2^{\prime} \operatorname{sini} 34-41$ yaş aralığındaki çalışanlar oluştururken, onu sırasıyla 26-33 (\%34,9), 18-25 (\%12,8) yaş aralığı izlemektedir. Katılımcıların eğitim durumlarına ilişkin veriler; \%46,9 lisans, \%24,4'ü lisansüstü, $\% 15,9$ önlisans ve $\% 11,6$ lise şeklinde dağılmıştır.

Katılımcıların çalıştıkları departmana ilişkin bilgiler incelendiğinde veriler; \%29 ön büro, \%20,5 insan kaynakları, \%15,3 kat hizmetleri, \%14,8 satış ve pazarlama, \%12,5 yiyecek-içecek bölümünde çalışmaktadır. Katılımcıların işletmedeki çalışma süreleri incelendiğinde; \%49,1'i 4-7 yıl, \%30,4'ü 1-3 yıl ve \%17,6'sı 8-11 yıldır. Sektördeki çalışma sürelerine göre ise \%41,8'i 12 yıl ve daha çok, \%36,4'ü 8-11 yıl, \%11,6'sı 1-3 yıl ve \%10,2'si 4-7 yıl şeklinde dağılmıştır. Anket uygulanan çalışanların aylık gelir durumlarına göre dağılımı ise sırasıyla, \%59,9'u 3501 TL ve üstü, \%26,7'si 3001- 3500 TL, \%11,4'ü 2501-3000 TL aylık gelire sahiptir.

Tablo 2'de sosyal sorumluluk ölçeğinin yapı geçerliliğine yönelik faktör analizi sonuçları sunulmuştur. Tablodaki bulgular incelendiğinde $\mathrm{KMO}$ değerleri $(\mathrm{KMO}=0,811)$, Bartlett küresellik testi sonuçları $(\chi 2=6255,48 ; \mathrm{p}=0,001)$ faktör analizinin uygulanabilirliğini ve örneklem yeterliliğini ortaya koymaktadır. Diğer taraftan sosyal sorumluluk ölçeğinin toplam varyansın \%70,839'unu açıklayan dört boyut altında toplandığ görülmüştür. Birinci boyut olan gönüllü sorumluluk alt boyutu toplam varyansın \%31,070'ini açıklarken ikinci boyut olan yasal sorumluluk alt boyutu \%19,365'ini açıklamaktadır. Benzer şekilde üçüncü boyut olan etik sorumluluk alt boyutu toplam varyansın \%10,590'ını açıklarken dördüncü boyut olan ekonomik sorumluluk alt boyutu toplam varyansın \%9,814'ünü açılamaktadır. Tabloya bakıldığında faktör yüklerinin 0,350 ile 0,873 arasında değiştiği görülmektedir. 
Tablo 2. Sosyal Sorumluluk Ölçeği Faktör Analizi Sonuçları

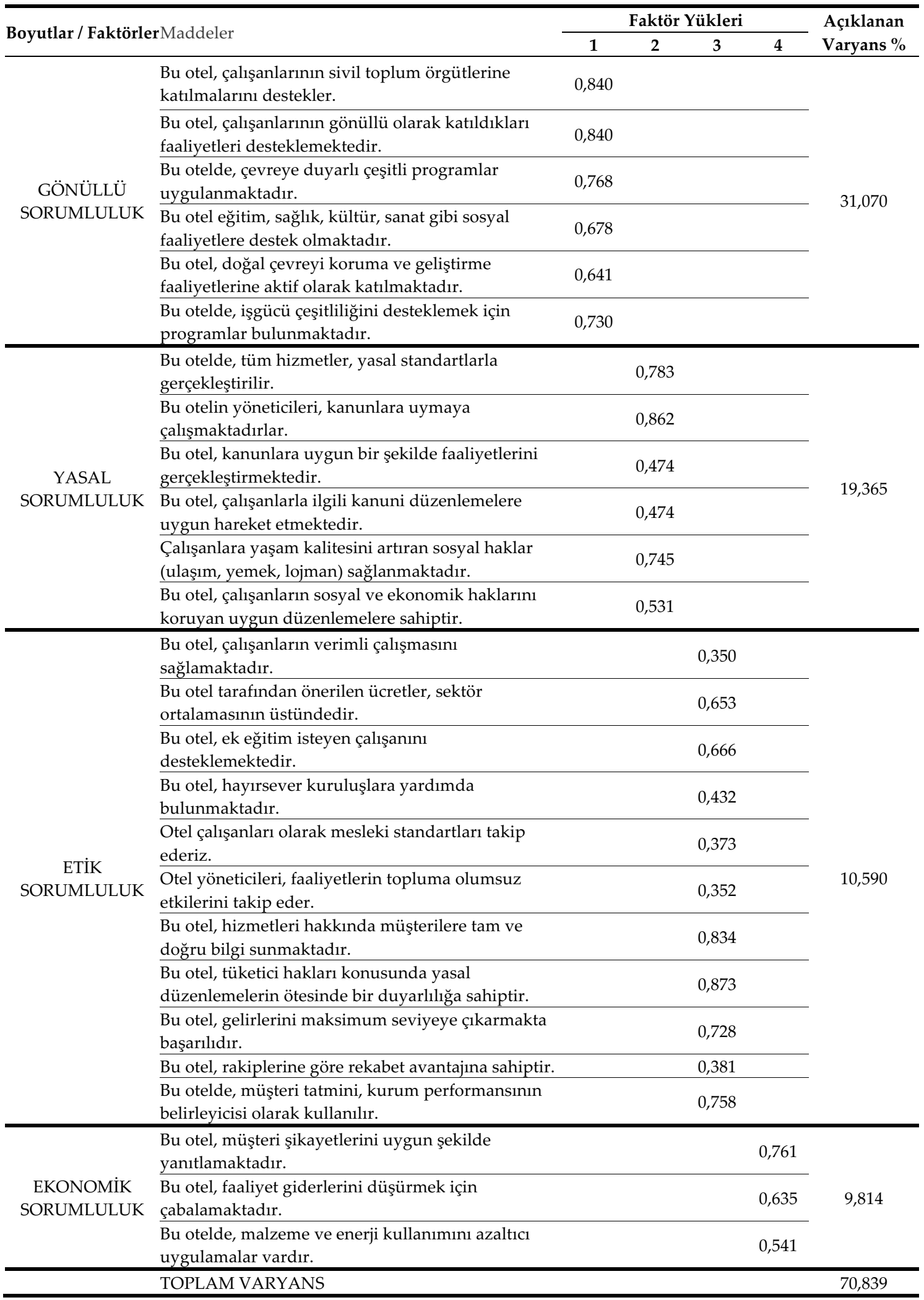

Kaiser-Meyer-Olkin $(K M O)=0,811 ;$ Barlett's Testi $\chi 2=6255,48 ; p=0,001$ 
Tablo 3'de örgütsel bağlılık ölçeğinin yapı geçerliliğine yönelik faktör analizi sonuçları sunulmuştur. Tablodaki bulgular incelendiğinde $\mathrm{KMO}$ değerleri $(\mathrm{KMO}=0,771)$, Bartlett küresellik testi sonuçları $(\chi 2=6255,48 ; p=0,001)$ faktör analizinin uygulanabilirliğini ve örneklem yeterliliğini ortaya koymaktadır. Diğer taraftan örgütsel bağlılık ölçeğinin toplam varyansın $\% 62,600$ 'ünü açıklayan üç boyut altında toplandığı görülmüştür. Birinci boyut olan duygusal bağlılık alt boyutu toplam varyansın \%29,441'ini açıklarken ikinci boyut olan devam bağlllığı alt boyutu \%19,719'unu açıklamaktadır. Benzer şekilde üçüncü boyut olan normatif bağllılı alt boyutu toplam varyansın \%13,440'ını açıklamaktadır. Tabloya bakıldığında faktör yüklerinin 0,302 ile 0,894 arasında değiştiği görülmektedir.

Tablo 3. Örgütsel Bağlllık Ölçeği Faktör Analizi

\begin{tabular}{|c|c|c|c|c|c|}
\hline \multirow{2}{*}{$\begin{array}{l}\text { Boyutlar / } \\
\text { Faktörler }\end{array}$} & \multirow[t]{2}{*}{ Maddeler } & \multicolumn{3}{|c|}{$\begin{array}{c}\text { Faktörler ve } \\
\text { Yükleri }\end{array}$} & \multirow{2}{*}{$\begin{array}{l}\text { Açıklanan } \\
\text { Varyans \% }\end{array}$} \\
\hline & & 1 & 2 & 3 & \\
\hline \multirow{6}{*}{$\begin{array}{l}\text { DUYGUSAL } \\
\text { BAĞLILIK }\end{array}$} & $\begin{array}{l}\text { Kariyerimin geri kalanını bu otelde geçirmekten çok } \\
\text { mutlu olurum. }\end{array}$ & 0,352 & & & \multirow{6}{*}{29,441} \\
\hline & $\begin{array}{l}\text { Bu otelin sorunlarını kendi sorunlarım gibi } \\
\text { hissediyorum. }\end{array}$ & 0,302 & & & \\
\hline & $\begin{array}{l}\text { Bu otele karşı güçlü bir “aidiyet” duygusu } \\
\text { hissetmiyorum. }\end{array}$ & 0,802 & & & \\
\hline & Bu otele karş1 “duygusal bağ” hissetmiyorum. & 0,802 & & & \\
\hline & $\begin{array}{l}\text { Bu otelde kendimi "ailenin bir parçası" gibi } \\
\text { hissetmiyorum. }\end{array}$ & 0,785 & & & \\
\hline & Bu otel benim için "çok özel" anlam taşıyor. & 0,894 & & & \\
\hline \multirow{6}{*}{$\begin{array}{c}\text { DEVAM } \\
\text { BAĞLILIĞI }\end{array}$} & $\begin{array}{l}\text { Şu an bu otelde çalışmak benim için istekten çok } \\
\text { gerekliliktir. }\end{array}$ & & 0,615 & & \multirow{6}{*}{19,719} \\
\hline & $\begin{array}{l}\text { İstesem bile şu an bu otelden ayrılmak benim için çok } \\
\text { zordur. }\end{array}$ & & 0,896 & & \\
\hline & $\begin{array}{l}\text { Şu an bu otelden ayrılmaya karar vermiş olsam, } \\
\text { hayatımın büyük bir kısmı altüst olurdu. }\end{array}$ & & 0,862 & & \\
\hline & $\begin{array}{l}\text { Bu otelden ayrılmayı düşünmek için çok az } \\
\text { seçeneğim olduğunu düşünüyorum. }\end{array}$ & & 0,799 & & \\
\hline & $\begin{array}{l}\text { Bu otele kendimden çok fazla bir şey vermemiş } \\
\text { olsaydım, başka bir yerde çalışmayı düşünürdüm. }\end{array}$ & & 0,495 & & \\
\hline & $\begin{array}{l}\text { Bu otelden ayrılmanın olumsuz sonuçlarından birisi } \\
\text { iş bulma alternatiflerimin az olmasıdır. }\end{array}$ & & 0,356 & & \\
\hline \multirow{7}{*}{$\begin{array}{l}\text { NORMATİF } \\
\text { BAĞLILIK }\end{array}$} & $\begin{array}{l}\text { Şu andaki işverenimle kalma zorunluluğu } \\
\text { hissetmiyorum. }\end{array}$ & & & 0,707 & \multirow{6}{*}{13,440} \\
\hline & $\begin{array}{l}\text { Çalıştığım otelden ayrılmak avantajlı olsa bile, şu } \\
\text { anda ayrılmanın doğru olduğunu düşünmüyorum. }\end{array}$ & & & 0,574 & \\
\hline & $\begin{array}{l}\text { Çalıştığım otelden şu anda ayrılırsam kendimi suçlu } \\
\text { hissederim. }\end{array}$ & & & 0,639 & \\
\hline & Bu otel sadakatimi hak ediyor. & & & 0,577 & \\
\hline & $\begin{array}{l}\text { Buradaki insanlara karşı bir sorumluluk duygum } \\
\text { olduğundan şu an bu otelden ayrılmak istemiyorum. }\end{array}$ & & & 0,827 & \\
\hline & Bu otele çok şey borçluyum. & \multirow{2}{*}{\multicolumn{3}{|c|}{$\frac{0,475}{\text { TOPLAM VARYANS }}$}} & \\
\hline & & & & & 62,600 \\
\hline
\end{tabular}

Kaiser-Meyer-Olkin $(K M O)=0,771 ;$ Barlett's Testi $\chi 2=6255,48 ; p=0,001$

Çalışmada kullanılan ölçeklerin güvenirlik analizine yönelik Cronbach's Alpha katsayıları incelendiğinde sosyal sorumluluk ölçeğine ilişkin Cronbach's Alpha katsayısının 0,873 olduğu, 
örgütsel bağlılık ölçeğine ilişkin Cronbach's Alpha katsayısının 0,708 olduğu görülmektedir. Bu değerlerin tamamı 0,70 olan kritik değerin üzerinde gerçekleşmiş olup bu da ölçeklerin güvenilir olduğunu göstermektedir (Kılıç, 2016: 47).

Katılımcların otel işletmelerinin sosyal sorumluluk uygulamalarına ilişkin görüşlerine yönelik bulgular incelendiğinde bütün maddelere 4'ün üzerinde oldukça olumlu görüş belirtildiği görülmektedir. En olumlu görüş “Bu otel, doğal çevreyi koruma ve geliştirme faaliyetlerine aktif olarak katılmaktadır" maddesine verilmiş olup, katılımcıların \%94,3'ü tam katılıyorum seçeneği ile olumlu görüş belirtmişlerdir $(\overline{\mathrm{X}}=4,94)$. "Bu otelde, çevreye duyarlı çeşitli programlar uygulanmaktadır" maddesine ise katılımcıların \%90,9'u tam katılıyorum seçeneği ile olumlu görüş belirtmişlerdir ( $\overline{\mathrm{X}}=4,88)$. "Bu otel, çalışanlarının sivil toplum örgütlerine katılmalarını destekler" ile "Bu otel, çalışanlarının gönüllü olarak katıldıkları faaliyetleri desteklemektedir" maddelerine ise katılımcıların \%77,6'sı tam katılıyorum seçeneği ile olumlu görüş belirtmişlerdir $(\overline{\mathrm{X}}=4,75)$.

Sosyal sorumluluk uygulamaları ölçeğinin "yasal sorumluluk" alt boyutuna ilişkin betimsel istatistikler incelendiğinde bütün maddelere 4'ün üzerinde oldukça olumlu görüş belirtildiği görülmektedir. En olumlu görüş "Bu otel, kanunlara uygun bir şekilde faaliyetlerini gerçekleştirmektedir" ile "Bu otel, çalışanlarla ilgili kanuni düzenlemelere uygun hareket etmektedir" maddelerine verilmiş olup, katılımcıların \%98'i tam katılıyorum seçeneği ile olumlu görüş belirtmişlerdir $(\overline{\mathrm{X}}=4,98)$. "Bu otelin yöneticileri, kanunlara uymaya çalışmaktadırlar" maddesine ise katılımcıların \%86,6'sı tam katılıyorum seçeneği ile olumlu görüş belirtmişlerdir ( $\overline{\mathrm{X}}=4,87)$. "Bu otelde, tüm hizmetler, yasal standartlarla gerçekleştirilir" maddesine ise katılımcıların \%86,1'sı tam katılıyorum seçeneği ile olumlu görüş belirtmişlerdir ( $\overline{\mathrm{X}}=4,86)$.

Sosyal sorumluluk uygulamaları ölçeğinin "etik sorumluluk" alt boyutuna ilişkin betimsel istatistikler incelendiğinde bütün maddelere 4 'ün üzerinde oldukça olumlu görüş belirtildiği görülmektedir. En olumlu görüş "Bu otel, hayırsever kuruluşlara yardımda bulunmaktadır" maddesine verilmiş olup, katılımcıların \%93,5'i tam katılıyorum seçeneği ile olumlu görüş belirtmişlerdir $(\overline{\mathrm{X}}=4,92)$. "Bu otelde, müşteri tatmini, kurum performansının belirleyicisi olarak kullanılır" maddesine ise katılımcıların \%88,1'i tam katılıyorum seçeneği ile olumlu görüş belirtmişlerdir $(\overline{\mathrm{X}}=4,86)$. "Bu otel, hizmetleri hakkında müşterilere tam ve doğru bilgi sunmaktadır" maddesine ise katılımcıların \%82,7'si tam katılıyorum seçeneği ile olumlu görüş belirtmişlerdir ( $\overline{\mathrm{X}}=4,81)$.

Örgütsel bağlllık ölçeğinin "duygusal bağlılık" alt boyutuna ilişkin betimsel istatistikler incelendiğinde duygusal bağlılık alt boyutunda katılımcılar görüşleri "Bu otele karşı güçlü bir "aidiyet" duygusu hissetmiyorum" ( $\overline{\mathrm{X}}=4,92)$, "Bu otele karşı "duygusal bağ" hissetmiyorum" ( $\overline{\mathrm{X}}=4,92)$ ve "Bu otelde kendimi "ailenin bir parçası" ( $\overline{\mathrm{X}}=4,84)$ gibi hissetmiyorum" maddelerine yönelik belirtmişlerdir.

Devam bağlıllı̆̆ alt boyutunda katılımcılar en olumlu görüşleri "Şu an bu otelde çalışmak benim için istekten çok gerekliliktir" ( $\bar{X}=4,20)$ ve "İstesem bile şu an bu otelden ayrılmak benim için çok zordur" ( $\overline{\mathrm{X}}=4,06)$ maddelerine yönelik belirtmişlerdir. Bunu, "Şu an bu otelden ayrılmaya karar vermiş olsam, hayatımın büyük bir kısmı altüst olurdu" ( $\overline{\mathrm{X}}=3,53)$, "Bu otelden ayrılmayı düşünmek için çok az seçeneğim olduğunu düşünüyorum" $(\bar{X}=3,26)$, "Bu otelden ayrılmanın olumsuz sonuçlarından birisi iş bulma alternatiflerimin az olmasıdır" ( $\bar{X}=2,66)$ ve "Bu otele kendimden çok fazla bir şey vermemiş olsaydım, başka bir yerde çalışmayı düşünürdüm" ( $\overline{\mathrm{X}}$ $=2,45$ ) maddeleri izlemektedir.

Örgütsel bağlılık ölçeğinin "normatif bağlllığı" alt boyutuna ilişkin betimsel istatistikler incelendiğinde normatif bağlılık alt boyutunda katılımcilar en olumlu görüşleri "Bu otel 
sadakatimi hak ediyor" ( $\overline{\mathrm{X}}=4,32)$ ve "Bu otele çok şey borçluyum" $(\overline{\mathrm{X}}=4,07)$ maddelerine yönelik belirtmişlerdir. Bunu, "Şu andaki işverenimle kalma zorunluluğu hissetmiyorum" ( $\overline{\mathrm{X}}=3,22)$, "Buradaki insanlara karşı bir sorumluluk duygum olduğundan şu an bu otelden ayrılmak istemiyorum" ( $\overline{\mathrm{X}}=3,18)$, "Çalıştığım otelden ayrılmak avantajlı olsa bile, şu anda ayrılmanın doğru olduğunu düșünmüyorum" ( $\bar{X}=3,10)$ ve "Çalıştığım otelden şu anda ayrılırsam kendimi suçlu hissederim" ( $\overline{\mathrm{X}}=2,70)$ maddeleri izlemektedir.

Katılımcıların sosyal sorumluluk uygulamalarına yönelik görüşleri ile örgütsel bağlllık düzeylerinin cinsiyete göre karşılaştırılmasına yönelik analiz sonuçları Tablo 4'de sunulmuştur.

Tablo 4. Sosyal Sorumluluk Uygulamaları ile Örgütsel Bağlllık Düzeylerinin Cinsiyete Göre Karşılaştırılması

\begin{tabular}{|c|c|c|c|c|c|}
\hline Ölçekler & Cinsiyet & $\overline{\mathrm{X}}$ & SS & $T$ & $\mathrm{p}$ \\
\hline \multirow{2}{*}{$\begin{array}{c}\text { Sosyal Sorumluluk } \\
\text { Uygulamaları }\end{array}$} & Kadın & 4,75 & 0,22 & \multirow{2}{*}{4,330} & \multirow{2}{*}{$0,000^{*}$} \\
\hline & Erkek & 4,63 & 0,27 & & \\
\hline \multirow{3}{*}{ Örgütsel Bağlılık } & Kadın & 3,73 & 0,50 & \multirow{3}{*}{3,573} & \multirow{3}{*}{$0,000^{*}$} \\
\hline & Erkek & 3,90 & 0,38 & & \\
\hline & Erkek & 4,82 & 0,34 & & \\
\hline
\end{tabular}

${ }^{*} p<0,05$

Katılımcıların beş yıldızlı otel işletmelerindeki sosyal sorumluluk uygulamalarına yönelik görüssleri ve örgütsel bağlllık düzeylerinin cinsiyete göre anlamlı bir farklılık gösterdiği $(p<0,05)$ tespit edilmiştir. Ortalama değerleri incelendiğinde kadın çalışanların $(\overline{\mathrm{X}}=4,75)$ otel işletmelerindeki sosyal sorumluluk uygulamalarına yönelik görüşlerinin erkeklere $(\overline{\mathrm{X}}=4,63)$ göre daha olumlu olduğu görülmektedir. Bu durumun kadınların erkeklere göre sorumluluk bilincinin daha yüksek olmasından kaynaklandığı söylenebilir. Bununla birlikte örgütsel bağlılık düzeyleri açısından bakıldığında erkeklerin $(\overline{\mathrm{X}}=3,90)$, kadınlardan $(\overline{\mathrm{X}}=3,73)$ daha yüksek bir bağlllığa sahip olduğu görülmektedir. Bu durumun erkeklerin toplumsal konumu sebebi ile çalışma zorunluluğu olmasından, kadınların ise evlendikten ve çocuk sahibi olduktan sonra kariyerlerinde yaşananabilecek güçlüklerin etkili olduğu düşünülebilir.

Tablo 5. Sosyal Sorumluluk Uygulamaları ile Örgütsel Bağlılık Düzeylerinin Medeni Duruma Göre Karşılaştırılması

\begin{tabular}{|c|c|c|c|c|c|}
\hline Ölçekler & $\begin{array}{l}\text { Medeni } \\
\text { Durum }\end{array}$ & $\bar{X}$ & SS & $\mathbf{T}$ & p \\
\hline \multirow{2}{*}{$\begin{array}{c}\text { Sosyal Sorumluluk } \\
\text { Uygulamaları }\end{array}$} & Bekar & 4,74 & 0,22 & \multirow{2}{*}{4,385} & \multirow{2}{*}{$0,000^{*}$} \\
\hline & Evli & 4,62 & 0,28 & & \\
\hline \multirow{3}{*}{ Örgütsel Bağlılık } & Bekar & 3,72 & 0,50 & \multirow{3}{*}{5,205} & \multirow{3}{*}{$0,000^{*}$} \\
\hline & Evli & 3,96 & 0,32 & & \\
\hline & Evli & 4,90 & 0,25 & & \\
\hline
\end{tabular}

${ }^{*} p<0,05$

Katılımcıların beş yıldızlı otel işletmelerindeki sosyal sorumluluk uygulamalarına yönelik görüşleri ile örgütsel bağlılık düzeylerinin medeni duruma göre anlamlı bir farklılık gösterdiği $(p<0,05)$ tespit edilmiştir. Ortalama değerleri incelendiğinde bekar çalışanların $(\bar{x}=4,74)$ otel işletmelerindeki sosyal sorumluluk uygulamalarına yönelik görüşlerinin evlilere $(\bar{X}=4,62)$ göre 
daha olumlu olduğu görülmektedir. Bununla birlikte örgütsel bağlılık düzeyleri açısından bakıldığında evlilerin $(\bar{X}=3,96)$, bekarlardan $(\bar{X}=3,72)$ daha yüksek bir bağlllı̆̆a sahip olduğu görülmektedir. Evli çalışanların eşlerine ve çocuklarına karşı üstlendikleri sorumluluklar örgütsel bağlllığı olumlu yönde etkileyebilmektedir.

Tablo 6. Sosyal Sorumluluk Uygulamaları ile Örgütsel Bağlılık Düzeylerinin Yaş Gruplarına Göre Karşılaştırılması

\begin{tabular}{|c|c|c|c|c|c|}
\hline Ölçekler & Yaş Grupları & $\overline{\mathrm{X}}$ & SS & $\mathbf{F}$ & p \\
\hline \multirow{4}{*}{$\begin{array}{l}\text { Sosyal Sorumluluk } \\
\text { Uygulamaları }\end{array}$} & $18-25$ yaş arası & $4,73^{a}$ & 0,16 & \multirow{4}{*}{4,062} & \multirow{4}{*}{$0,007^{*}$} \\
\hline & 26-33 yaş arası & $4,74^{\mathrm{a}}$ & 0,26 & & \\
\hline & 34-41 yaş arası & $4,64^{\mathrm{b}}$ & 0,24 & & \\
\hline & 42 ve üzeri & $4,63^{\mathrm{b}}$ & 0,37 & & \\
\hline \multirow{7}{*}{ Örgütsel Bağl1lık } & $18-25$ yaş arası & $4,05^{\mathrm{a}}$ & 0,45 & \multirow{7}{*}{18,597} & \multirow{7}{*}{$0,000^{*}$} \\
\hline & $26-33$ yaş arası & $3,64^{c}$ & 0,50 & & \\
\hline & 34-41 yaş arası & $3,85^{\mathrm{b}}$ & 0,34 & & \\
\hline & 42 ve üzeri & $4,10^{\mathrm{a}}$ & 0,24 & & \\
\hline & 26-33 yaş arası & $4,61^{b}$ & 0,36 & & \\
\hline & $34-41$ yaş arası & $4,94^{\mathrm{a}}$ & 0,17 & & \\
\hline & 42 ve üzeri & $4,82^{\mathrm{a}}$ & 0,38 & & \\
\hline
\end{tabular}

${ }^{*} p<0,05 a, b$ ve c harfleri içeren gruplar arasında anlamlı bir farkllık vardır.

Katılımcıların beş yıldızlı otel işletmelerindeki sosyal sorumluluk uygulamalarına yönelik görüşleri ile örgütsel bağlılık düzeylerinin yaş gruplarına göre anlamlı bir farklılık gösterdiği $(p<0,05)$ tespit edilmiştir. Ortalama değerleri incelendiğinde $18-25$ yaş $(\bar{X}=4,73)$ ve $26-33$ yaş $(\bar{X}$ $=4,74)$ aralığındaki çalışanların otel işletmelerindeki sosyal sorumluluk uygulamalarına yönelik görüşlerinin 34-41 yaş $(\overline{\mathrm{X}}=4,64)$ ile 42 yaş ve üzerindekilere $(\overline{\mathrm{X}}=4,64)$ göre daha olumlu olduğu görülmektedir. Bununla birlikte örgütsel bağlılık düzeyleri açısından bakıldığında 42 yaş ve üzerindekilerin $(\bar{X}=4,10), 18-25$ yaş $(\bar{X}=4,05), 34-41$ yaş $(\bar{X}=3,85)$ ve $26-33$ yaş $(\bar{X}=3,64)$ aralığındakilere göre daha yüksek bir bağllı̆̆g sahip olduğu görülmektedir. Örgütsel bağlllık düzeylerinin 42 yaş ve üzerindekilerde yüksek olması iş değişikliklerinin olumsuz etkileriyle karşılaşmak yerine; bulundukları işletmelerde çalışmaya devam etme isteğinden kaynaklandığı söylenebilir.

Tablo 7. Sosyal Sorumluluk Uygulamaları ile Örgütsel Bağlılık Düzeylerinin Eğitim Durumuna Göre Karşılaştırılması

\begin{tabular}{|c|c|c|c|c|c|}
\hline Ölçekler & Eğitim Durumu & $\overline{\bar{X}}$ & SS & $F$ & $\mathbf{P}$ \\
\hline \multirow{4}{*}{$\begin{array}{l}\text { Sosyal Sorumluluk } \\
\text { Uygulamaları }\end{array}$} & Lise ve alt1 & $4,73^{a}$ & 0,29 & \multirow{4}{*}{4,546} & \multirow{4}{*}{$0,004^{*}$} \\
\hline & Ön lisans & $4,57 \mathrm{~b}$ & 0,21 & & \\
\hline & Lisans & $4,71^{a}$ & 0,24 & & \\
\hline & Lisansüstü & $4,69^{a}$ & 0,28 & & \\
\hline \multirow{7}{*}{ Örgütsel Bağlllık } & Lise ve altı & $4,24^{\mathrm{b}}$ & 0,19 & \multirow{7}{*}{28,235} & \multirow{7}{*}{$0,000^{*}$} \\
\hline & Ön lisans & $3,82^{a}$ & 0,40 & & \\
\hline & Lisans & $3,66^{c}$ & 0,50 & & \\
\hline & Lisansüstü & $3,95^{\mathrm{a}}$ & 0,20 & & \\
\hline & Ön lisans & $4,83^{a}$ & 0,35 & & \\
\hline & Lisans & $4,6^{\mathrm{b}}$ & 0,35 & & \\
\hline & Lisansüstü & $4,99 a$ & 0,43 & & \\
\hline
\end{tabular}

${ }^{*} p<0,05 a, b$ ve c harfleri içeren gruplar arasında anlamlı bir farklılık vardır. 
Katılımcların sosyal sorumluluk uygulamalarına yönelik görüşleri ile örgütsel bağlılık ve iş performans düzeylerinin eğitim duruma göre karşılaştırılmasına yönelik varyans analizi sonuçları bulgulara göre, katılımcıların beş yıldızlı otel işletmelerindeki sosyal sorumluluk uygulamalarına yönelik görüşleri ile örgütsel bağlllık düzeylerinin eğitim durumuna göre anlamlı bir farklılık gösterdiği $(\mathrm{p}<0,05)$ tespit edilmiştir. Ortalama değerleri incelendiğinde lise ve altı eğitim düzeyindeki çalışanların $\left(\frac{X}{x}=4,73\right)$ otel işletmelerindeki sosyal sorumluluk uygulamalarına yönelik görüşlerinin lisans $\left({ }^{\bar{X}}=4,71\right)$, lisansüstü $\left({ }^{X}=4,69\right)$ ve ön lisans $\left({ }^{X}=4,57\right)$ eğitimi alanlara göre daha olumlu olduğu görülmektedir. Bununla birlikte örgütsel bağlllık düzeyleri açısından bakıldığında lise ve altı eğitim düzeyindekilerin $\left({ }^{X}=4,24\right)$, lisansüstü ( ${ }^{X}$ $=3,95)$, ön lisans ( $\left.{ }^{X}=3,82\right)$ ve lisans ( $\left.{ }^{X}=3,66\right)$ düzeyindekilere göre daha yüksek bir bağlllığa sahip olduğu görülmektedir. Bu durumun lise ve altı düzeyde eğitim alan çalışanların işlerini kaybetmesi durumunda iş bulamayacağı endişesinden kaynaklı olabilmektedir.

Tablo 8. Sosyal Sorumluluk Uygulamaları ile Örgütsel Bağlılık Düzeylerinin Çalışılan Departmana Göre Karşılaştırılması

\begin{tabular}{lccccc}
\hline Ölçekler & Departman & $\overline{\mathrm{X}}$ & SS & F & P \\
\hline & Ön büro & $4,6^{\mathrm{b}}$ & 0,27 & & \\
Sosyal Sorumluluk & Satıs ve Pazarlama & $4,80^{\mathrm{a}}$ & 0,10 & & \\
Uygulamaları & İnsan Kaynakları & $4,80^{\mathrm{a}}$ & 0,19 & \multirow{2}{*}{16,785} & $0,000^{*}$ \\
& Yiyecek-İçecek & $4,45^{\mathrm{c}}$ & 0,31 & & \\
& Kat Hizmetleri & $4,6^{\mathrm{b}}$ & 0,27 & & \\
& Diğer** & $4,52^{\mathrm{c}}$ & 0,10 & & \\
& Ön büro & $3,97^{\mathrm{b}}$ & 0,32 & & \\
& Satıs ve Pazarlama & $3,66^{\mathrm{c}}$ & 0,22 & & \\
Örgütsel Bağlllik & İnsan Kaynakları & $3,53^{\mathrm{c}}$ & 0,64 & \multirow{2}{*}{22,139} & $0,000^{*}$ \\
& Yiyecek-İçecek & $3,84^{\mathrm{b}}$ & 0,35 & & \\
& Kat Hizmetleri & $4,18^{\mathrm{a}}$ & 0,25 & & \\
& Diğer** & $3,72^{\mathrm{c}}$ & 0,14 & & \\
\hline
\end{tabular}

${ }^{*} p<0,05 a, b$ ve c harfleri içeren gruplar arasında anlamlı bir farklılık vardır.

** Muhasebe, teknik, satınalma ve güvenlik $v b$.

Katılımcıların sosyal sorumluluk uygulamalarına yönelik görüşleri ile örgütsel bağlllık düzeylerinin çalıştıkları departmana göre karşılaştırılmasına yönelik varyans analizi sonuçları göre, katılımcıların beş yıldızlı otel işletmelerindeki sosyal sorumluluk uygulamalarına yönelik görüşleri ile örgütsel bağlılık düzeylerinin çalışılan departmana göre anlamlı bir farklılık gösterdiği $(p<0,05)$ tespit edilmiştir. Ortalama değerleri incelendiğinde satış ve pazarlama $(\overline{\mathrm{X}}$ $=4,80)$ ile insan kaynakları $(\bar{X}=4,80)$ departmanında çalışanların otel işletmelerindeki sosyal sorumluluk uygulamalarına yönelik görüşlerinin ön büro $(\bar{X}=4,69)$, kat hizmetleri $(\bar{X}=4,67)$, diğer $(\overline{\mathrm{X}}=4,52)$ ve yiyecek-içecek $(\overline{\mathrm{X}}=4,45)$ departmanındakilere göre daha olumlu olduğu görülmektedir. İnsan kaynakları, satış ve pazarlama departmanlarda çalışanların yaptıkları iş nedeni ile sosyal sorumluluk uygulamalarında daha aktif rol almaları etkili olabilmektedir. Bununla birlikte örgütsel bağlılık düzeyleri açısından bakıldığında kat hizmetleri $(\bar{X}=4,18)$ departmanındakilerin, ön büro $(\bar{X}=3,97)$, yiyecek-içecek $(\bar{X}=3,84)$, diğer $(\bar{X}=3,72)$, satış ve pazarlama $(\overline{\mathrm{X}}=3,66)$ ile insan kaynakları $(\overline{\mathrm{X}}=3,53)$ departmanındakilere göre daha yüksek bir bağlılığa sahip olduğu görülmektedir. Kat hizmetleri ve ön büro departmanında çalışanların örgütsel bağlılık düzeylerinin oldukça yüksek olması, çalışanların pozisyonlarından memnun olmaları ile ilişkilendirilebilir. 
Tablo 9. Sosyal Sorumluluk Uygulamaları ile Örgütsel Bağlılık Düzeylerinin Oteldeki Çalışma Süresine Göre Karşılaştırılması

\begin{tabular}{cccccc}
\hline Ölçekler & Çalışma Süresi & $\overline{\mathrm{X}}$ & SS & F & P \\
\hline \multirow{2}{*}{ Sosyal Sorumluluk } & 3 yıl ve altı & $4,60^{\mathrm{b}}$ & 0,25 & & \\
Uygulamaları & 4-7 yıl arası & $4,73^{\mathrm{a}}$ & 0,24 & 8,819 & $0,000^{*}$ \\
& 8 yıl ve üzeri & $4,70^{\mathrm{a}}$ & 0,30 & & \\
\hline Örgütsel Bağlılık & 3 yıl ve altı & $3,85^{\mathrm{a}}$ & 0,44 & & \\
& 4-7 yıl arası & $3,81^{\mathrm{a}}$ & 0,50 & & \multirow{2}{*}{0,735} \\
& 8 yıl ve üzeri & $3,84^{\mathrm{a}}$ & 0,24 & 0,308 & \\
& 4-7 yıl arası & $4,80^{\mathrm{a}}$ & 0,32 & & \\
\hline
\end{tabular}

${ }^{*} p<0,05$ a ve $b$ harfleri içeren gruplar arasında anlamlı bir farklılık vardır.

Katılımcıların sosyal sorumluluk uygulamalarına yönelik görüşleri ile örgütsel bağlllık düzeylerinin oteldeki çalışma süresine göre karşılaştırılmasına yönelik varyans analizi sonuçları göre, katılımcıların beş yıldızlı otel işletmelerindeki sosyal sorumluluk uygulamalarına yönelik görüşlerinin oteldeki çalışma süresine göre anlamlı bir farklılık gösterdiği $(\mathrm{p}<0,05)$, buna karşılık örgütsel bağlllık düzeylerinin ise oteldeki çalışma süresine göre anlamlı bir farklılık göstermediği $(p>0,05)$ tespit edilmiştir. Ortalama değerleri incelendiğinde 4-7 yıl arasında otelde çalışanların ( $\overline{\mathrm{X}}=4,73$ ) otel işletmelerindeki sosyal sorumluluk uygulamalarına yönelik görüşlerinin 8 yıl ve üzeri $(\bar{X}=4,70)$ ile 3 yıl ve altındakilere göre daha olumlu olduğu görülmektedir. Bununla birlikte örgütsel bağlılık düzeyleri açısından bakıldığında ortalama değerlerin 3,80'in üzerinde olduğu görülmektedir.

Tablo 10. Sosyal Sorumluluk Uygulamaları ile Örgütsel Bağlllık Düzeylerinin Sektördeki Çalışma Süresine Göre Karşılaştırılması

\begin{tabular}{|c|c|c|c|c|c|}
\hline Ölçekler & $\begin{array}{c}\text { Sektördeki } \\
\text { Çalışma Süresi }\end{array}$ & $\overline{\mathrm{X}}$ & SS & $\mathbf{F}$ & $\mathbf{P}$ \\
\hline \multirow{4}{*}{$\begin{array}{l}\text { Sosyal Sorumluluk } \\
\text { Uygulamaları }\end{array}$} & $1-3$ y1l arası & $4,77^{\mathrm{a}}$ & 0,10 & \multirow{4}{*}{11,647} & \multirow{4}{*}{$0,004^{*}$} \\
\hline & 4-7 y1l arası & $4,4^{c}$ & 0,21 & & \\
\hline & 8-11 yıl arası & $4,65^{\mathrm{b}}$ & 0,30 & & \\
\hline & 12 yıl ve üzeri & $4,74^{\mathrm{a}}$ & 0,23 & & \\
\hline \multirow{4}{*}{ Örgütsel Bağlılık } & $1-3$ yıl arası & $4,10^{\mathrm{a}}$ & 0,44 & \multirow{4}{*}{24,153} & \multirow{4}{*}{$0,000^{*}$} \\
\hline & 4-7 y1l arası & $3,53^{c}$ & 0,24 & & \\
\hline & $8-11$ yıl arası & $3,68^{b}$ & 0,51 & & \\
\hline & 12 yıl ve üzeri & $3,96^{\mathrm{a}}$ & 0,30 & & \\
\hline
\end{tabular}

${ }^{*} p<0,05$ a b ve c harfleri içeren gruplar arasinda anlamlı bir farklilık vardır.

Katılımcların sosyal sorumluluk uygulamalarına yönelik görüşleri ile örgütsel bağlllık düzeylerinin sektördeki çalışma süresine göre karşılaştırılmasına yönelik varyans analizi sonuçları göre, katılımcıların beş yıldızlı otel işletmelerindeki sosyal sorumluluk uygulamalarına yönelik görüşleri ile örgütsel bağlllık düzeylerinin sektördeki çalışma süresine göre anlamlı bir farklılık gösterdiği $(\mathrm{p}<0,05)$ tespit edilmiştir. Ortalama değerleri incelendiğinde 1-3 yıl arasında çalışanlar $(\bar{X}=4,77)$ ile 12 yıl ve üzeri $(\bar{X}=4,74)$ süredir çalışanların otel işletmelerindeki sosyal sorumluluk uygulamalarına yönelik görüşlerinin 8-11 yıl $(\overline{\mathrm{X}}=4,65)$ ve $4-7$ yıl $(\overline{\mathrm{X}}=4,49)$ arasında çalışanlara göre daha olumlu olduğu görülmektedir. Bununla birlikte örgütsel bağlllık düzeyleri açısından bakıldığında 1-3 yıl arasında çalışanların $(\overline{\mathrm{X}}=4,10), 12$ yıl ve üzeri $(\overline{\mathrm{X}}=3,96), 8-11$ yıl ( 
$\overline{\mathrm{X}}=3,68)$ ve $4-7$ yıl $(\overline{\mathrm{X}}=3,53)$ arasında çalışanlara göre daha yüksek bir bağlllığa sahip olduğu görülmektedir.

Tablo 11. Sosyal Sorumluluk Uygulamaları ile Örgütsel Bağlılık Düzeylerinin Gelir Düzeyine Göre Karşılaştırılması

\begin{tabular}{cccccc}
\hline Ölçekler & Gelir Düzeyi & $\overline{\mathrm{X}}$ & SS & F & P \\
\hline \multirow{2}{*}{ Sosyal Sorumluluk } & 3000 TL ve altı & $4,76^{\mathrm{a}}$ & 0,17 & & \\
Uygulamaları & 3001 TL-3500 TL arası & $4,59^{\mathrm{b}}$ & 0,26 & 9,90 & $0,000^{*}$ \\
& 3501 TL ve üstü & $4,71^{\mathrm{a}}$ & 0,26 & & \\
\hline & 3000 TL ve altı & $4,10^{\mathrm{a}}$ & 0,43 & & \\
Örgütsel Bağlılık & 3001 TL-3500 TL arası & $3,83^{\mathrm{b}}$ & 0,37 & \multirow{2}{*}{11,67} & $0,000^{*}$ \\
& 3501 TL ve üstü & $3,77^{\mathrm{b}}$ & 0,45 & & \\
\hline 3501 TL ve üstü & $4,81^{\mathrm{b}}$ & 0,33 & & \\
\hline
\end{tabular}

${ }^{*} p<0,05$ a ve $b$ harfleri içeren gruplar arasında anlamlı bir farklılık vardır.

Katılımcıların sosyal sorumluluk uygulamalarına yönelik görüşleri ile örgütsel bağlllık düzeylerinin sektördeki gelir düzeyine göre karşılaştırılmasına yönelik varyans analizi bulguları incelendiğinde; katılımcıların beş yıldızlı otel işletmelerindeki sosyal sorumluluk uygulamalarına yönelik görüşleri ile örgütsel bağlılık düzeylerinin gelir düzeylerine göre anlamlı bir farklılık gösterdiği $(\mathrm{p}<0,05)$ tespit edilmiştir. Ortalama değerleri incelendiğinde $3000 \mathrm{TL}$ ve altında maaşı olanların $(\overline{\mathrm{X}}=4,76)$ otel işletmelerindeki sosyal sorumluluk uygulamalarına yönelik görüşlerinin 3501 TL ve üzeri $(\bar{X}=4,71)$ ve 3001 TL-3500 TL arasında $(\bar{X}=4,59)$ maaşı olanlara göre daha olumlu olduğu görülmektedir. Bununla birlikte örgütsel bağlılık düzeyleri açısından bakıldığında en yüksek bağlılığa sahip olanların 3000 TL ve altında maaş alanlar $(\bar{X}=4,10)$ görülmektedir.

Sosyal sorumluluk uygulamaları ile örgütsel bağlılık ölçekleri ve boyutlarına ilişkin ortalama ve standart sapmaları Tablo 12' de verilmiştir.

Tablo 12. Sosyal Sorumluluk Uygulamaları ve Örgütsel Bağlılık Boyutlarının Ortalama ve Standart Sapmaları

\begin{tabular}{|c|c|c|c|}
\hline Ölçek & Boyutlar & $\overline{\bar{X}}$ & SS \\
\hline & Gönüllü Sorumluluk & 4,72 & 0,40 \\
\hline SOSYAL & Yasal Sorumluluk & 4,75 & 0,25 \\
\hline SORUMLULUK & Etik Sorumluluk & 4,60 & 0,37 \\
\hline UYGULAMALARI & Ekonomik Sorumluluk & 4,79 & 0,31 \\
\hline & Genel Sosyal Sorumluluk & 4,68 & 0,26 \\
\hline \multirow{4}{*}{ ÖRGÜTSEL BAĞLILIK } & Duygusal Bağlılık & 4,70 & 0,32 \\
\hline & Devam Bağllı̆ı̆ & 3,36 & 0,93 \\
\hline & Normatif Bağlllık & 3,35 & 0,79 \\
\hline & Genel Örgütsel Bağllılık & 3,80 & 0,44 \\
\hline
\end{tabular}

Tablo 12'deki bulgular incelendiğinde sosyal sorumluluk uygulamaları ölçeğinin genel ortalamasının $(\overline{\mathrm{X}}=4,68)$ olduğu görülmektedir. Sosyal sorumluluk boyutları içerisinde en düşük ortalama "Etik Sorumluluk" $(\overline{\mathrm{X}}=4,60)$ iken, "Ekonomik Sorumluluk" $(\overline{\mathrm{X}}=4,79)$ ve "Yasal Sorumluluk" $(\overline{\mathrm{X}}=4,75)$ boyutlarına ait görüşlerin ise oldukça yüksek olduğu görülmektedir. Diğer taraftan örgütsel bağlllık ölçeğinin genel ortalamasının ise $(\bar{X}=3,80)$ olduğu ve en yüksek 
ortalamanin "Duygusal Bağlllık" ( $\overline{\mathrm{X}}=4,70)$ boyutuna ait olduğu, "Devam Bağlllığı" $(\overline{\mathrm{X}}=3,36)$ ve "Normatif Bağlllık" ( $\overline{\mathrm{X}}=3,35)$ ortalamalarının ise neredeyse aynı olduğu görülmektedir. İş performansı ölçeğine ilişkin ortalama ise $(\bar{X}=4,81)$ olarak tespit edilmiştir. Buna göre beş yıldızlı otel işletmelerinde sosyal sorumluluk uygulamalarını ekonomik sorumluluk boyutunda yoğunlaştığı, etik sorumluluklar boyutuna ise daha az odaklandıkları görülmektedir. Başka bir deyişle çalışanlara göre; işletmeler ekonomik sorumluluklarını yerine getirilmesinde daha başarılı iken etik sorumluluklarını göz ardı etmektedirler. Bununla birlikte çalışanların duygusal bağlılıklarının oldukça güçlü olduğu, devam ve normatif bağlllıklarının ise buna göre daha düşük olduğu anlaşılmaktadır. Şahinoğlu'nun (2011: 79) hizmet sektöründe yapmış olduğu çalışmada da çalışanların en yüksek algı düzeyinin yasal sorumluluk boyutuna ait olduğu, bağlılığı ise bütün alt boyutları ile hissettikleri bulunmuştur.

Sosyal sorumluluk uygulamaları ile örgütsel bağlılık arasındaki ilişkiye yönelik Korelasyon Analizi (Pearson Korelasyon Katsayısı) sonuçları incelendiğinde, genel sosyal sorumluluk uygulamaları ile genel örgütsel bağlılık arasında anlamlı bir ilişki $(\mathrm{r}=0,054)$ bulunmamıştır. Başka bir ifade ile çalışanların otel işletmelerinin sosyal sorumluluk uygulamalarına yönelik görüşlerinin örgütsel bağlılıkları ile herhangi bir ilişkisinin olmadığı ortaya çıkmışır. Konuyla ilgili olarak farklı bir sektörde yapılan çalışmada Bayraktaroğu vd., (2014: 99), çalışanların sosyal sorumluluk uygulamalarına yönelik görüşleri ile örgütsel bağlılık düzeyleri arasında anlamlı bir ilişki olduğunu belirlemişlerdir.

Sosyal sorumluluk ölçeğinin alt boyutları arasındaki ilişkilere bakıldığında ise sosyal sorumluluğun etik sorumluluk boyutu ile arasında pozitif, oldukça yüksek ve anlamlı bir ilişki $(\mathrm{r}=0,903, \mathrm{p}=0,000<0,01)$ olduğu görülmektedir. Başka bir ifade ile otel çalışanlarının işletmelerin sosyal sorumluluk uygulamalarına yönelik en yüksek pozitif görüşlerinin etik sorumluluk boyutunda olduğu tespit edilmiştir. Etik davranış kuralları genel olarak herkes tarafından beklenen davranışlar olduğundan işletmelerin uygulamalarında bunlara ağırlık vermesinin çalışanlarını memnun ettiği görülmektedir. Diğer taraftan ekonomik sorumluluk boyutu ile ise pozitif, yüksek ve anlamlı bir ilişkisi $(r=0,742, \mathrm{p}=0,000<0,01)$ olduğu görülmektedir. İşletmelerin ve çalışanların temel amacının varlıklarını devam ettirmek olduğu düşünüldüğünde ekonomik boyutla olan bu ilişkisinin beklenen bir ilişki olduğunu söylemek mümkündür. Sosyal sorumluluğun gönüllü sorumluluk boyutu ile arasında ise pozitif, orta düzeyde ve anlamlı bir ilişkisi $(r=0,679, p=0,000<0,01)$ olduğu görülmektedir. İşletmelerin bu boyuttaki uygulamalarının daha zayıf olmasının, gönüllü sorumlulukların Carroll'un (1991:4) geliştirdiği sosyal sorumluluk piramidinin en üst basamağında yer alan ve sosyal olarak işletmelerden gerçekleştirmesi arzu edilen (Windsor, 2001: 30) sorumluluklar olduğundan kaynaklandığı söylenebilir. Diğer taraftan Mirzayeva vd.,'́nin (2016: 28) dört ve beş yıldızlı otellerde gerçekleştirdiği çalışma sonucunda ise işletmelerin sosyal sorumluluk uygulamalarında en çok gönüllü sorumluluklarına yöneldikleri ve bunu sırasıyla etik, yasal ve ekonomik sorumluluk boyutlarının izlediği tespit edilmiştir.

Örgütsel bağlılık ölçeğinin alt boyutları arasındaki ilişkiye bakıldığında ise örgütsel bağlılık ile devam bağlılığı arasında pozitif, yüksek ve anlamlı bir ilişki $(r=0,866, p=0,000<0,01)$ olduğu görülmektedir. Başka bir deyişle çalışanların işletmeye harcadığı emek ve zaman ağır bastı̆̆ için işletmeye bağlılık hissettiği tespit edilmiştir. Diğer taraftan duygusal bağlılık ile olan ilişkisinin de pozitif, orta düzeyde ve anlamlı $(\mathrm{r}=0,602, \mathrm{p}=0,000<0,01)$ olduğu görülmektedir. $\mathrm{Bu}$ da çalışanların işletmelerine karşı gönülden bir bağlılık hissettiğini ifade etmektedir. Normatif bağlllık boyutu ile ise pozitif, orta ve anlamlı bir ilişkisi olduğu tespit edilmiştir. Tükeltürk vd.,'nin (2012: 104) otel işletmesi çalışanları ile gerçekleştirdiği çalışma sonucunda ise örgütsel bağlllık ile normatif bağlllık boyutu arasında yüksek, pozitif ve anlamlı bir ilişki olduğu tespit edilmiştir. 


\section{SONUÇ}

Sosyal birer varlık olan işletmelerin içerisinde faaliyet gösterdikleri topluma karşı birçok sorumluluğu bulunmaktadır ve işletmeler günümüzde bu sorumluluklarını kurumsal bir bilinçle yerine getirerek sürdürülebilirliklerini devam ettirmeye çalışmaktadırlar. Bu doğrultuda sosyal sorumluluk kavramını içselleştiren işletmelerden iç ve dış çevresine karşı ekonomik, yasal, etik ve gönüllülük boyutlarında uygulamalarda bulunması beklenmektedir. İşletmelerin varlığını devam ettirebilmesi için öncelikle ekonomik olarak sorumluluklarını yerine getirmesi ve karlılık düzeyini artırması hedeflenmektedir. Ancak bunu yaparken her zaman yasalara uyması ve etik sorumluluklarını göz önünde bulundurması iç ve dış çevresi tarafından beklenmektedir. Rekabet avantajını elinde bulundurmak isteyen işletmelerin bunlara ek olarak iç ve dış çevresindeki değerini arttıracak gönüllü sorumluluklarda bulunması ise oldukça önemlidir (Carroll, 1991: 42).

Teknolojik gelişmelere rağmen emek yoğun işletmeler olmaya devam eden turizm işletmelerinde hizmetin kesintisiz devam etmesi ve müşteri memnuniyeti büyük ölçüde çalışanların kalitesi ile mümkün olabilmektedir (Özdemir ve Akpınar, 2002: 85; Ünlüönen ve Şahin, 2011: 2; Davras ve Gülmez, 2013: 167). Varlığını başarılı bir şekilde devam ettirebilmesi insan gücüne bağlı olan turizm işletmelerinin kalifiye ve başarılı çalışanlarını elinde tutabilmesi ve örgüte bağlılıklarını arttırabilmesi en önemli amaçlarından biridir. Örgüte güçlü bir bağlılık hisseden çalışanlar işini iyi yapmak için yüksek bir performans sergileyeceklerdir (Çuhadar ve Gencer, 2016: 1326). Diğer bir deyişle çalışanın iş yerine psikolojik olarak bağlanmasını ifade eden örgütsel bağlılık kavramı çalışanların verimliliklerini ve performanslarını da etkileyecektir (Morrow, 1983: 491, Yalçın ve İplik, 2005: 397).

Örgütsel bağlılık kavramı çalışanların davranış ve tutumlarının birer sonucu olduğundan bu sonucu arttırmayı etkileyen faktörlerin belirlenmesi işletmelerin başarılı bir şekilde faaliyetlerine devam edebilmesi açısından önemlidir. Literatür incelendiğinde ise, yaş, cinsiyet, deneyim, yapılan işin önemi ve alınan destek, karar alma sürecine katılım ve işin içinde yer alma, medeni durum ve ücret dışında sağlanan haklar, etik değerler, liderlik davranışları, diğer iş olanakları ve çalışanlara gösterilen ilgi, iş gücü farklılığı, terfi olanakları, ücret ve çalışma arkadaşları, iş güvenliği, tanınma ve yabancılaşma, örgütsel vatandaşlık, örgütsel adalet, personel güçlendirme, güven ve iş tatmini, çaresizlik, iş saatleri, ödüller ve rutinlik gibi faktörlerin örgütsel bağlllığ1 etkilediği tespit edilmiştir (Mowday vd., 1982; Rosin ve Korabik, 1995; Meyer ve Allen, 1997; Balay, 2000; Çetin, 2004; Bayram, 2005; Boylu vd., 2007; Işık ve Yasım, 2017; Erkol Bayram, 2018; Bulşu ve Gümüş, 2018; Erdoğdu ve Sökmen, 2019; Salha ve Ulema, 2020).

Sosyal sorumluluk ölçeğinin gönüllü sorumluluk alt boyutunda işletmelerin doğal çevreye duyarlı çeşitli programlar ile çevreyi koruma ve geliştirme faaliyetlerine yönelik yaptığ1 uygulamalarının oldukça olumlu karşılandığı gözlemlenmiştir. Kaynaklarının büyük bir kısmını faaliyet gösterdiği doğal çevrenin güzelliklerinden alan otel işletmeleri, sürdürülebilir bir şekilde varlığına devam edebilmek için bu tarz uygulamalarda bulunması gerektiğini fark etmiş ve buna yönelik uygulamalarda bulunmaya başlamıştır. Çalışanların bu yöndeki olumlu algılamalarını da bu duruma bağlayabiliriz. Nitekim literatürdeki konuyla ilgili yapılan çalışamalara bakıldığında; doğal çevreyi koruma ve geliştirme faaliyetlerine yönelik sosyal sorumluluk uygulamalarının olumlu karşılandığı görülmektedir (Minareci, 2007: 115; Çalışkan, 2010: 82; Lee vd., 2012: 751; Serinikli, 2018: 298-299; Ata ve Ataman, 2020: 266-267, Boğan, 2020: 389-390).

Sosyal sorumluluk ölçeğinin etik sorumluluk alt boyutunda ise işletmelerin hayırsever kuruluşlara yardımda bulunduğuna, müşterilere sunulan bilgilerin eksiksiz, doğru olduğuna ve sonuç olarak müşteri tatmininin de işletmenin performansının belirleyicisi olduğuna dair olumlu görüşlerin bildirildiği görülmüştür. Buna karşılık çalışanlara sunulan ücretlerde sektör ortalamasının altında kalındığı ve çalışanların beklentilerini karşılamadığı tespit edilmiştir. Bu 
durum ise işletmelerin etik sorumluluklarını uygularken toplumu ve müşterilerini hedef aldığı, çalışanlarını ise göz ardı ettiği şeklinde yorumlanabilir. Pelit ve Arslantürk'ün (2011: 173) turizm sektörünün çalışan adayları olan turizm eğitimi alan öğrenciler üzerinde yaptığı araştırmada da etik sorumluluk görüşlerinde benzer sonuçlar elde edilmiştir. Etik sorumluluk uygulamalarını İstanbul'daki dört ve beş yıldızlı otel işletmelerinin yöneticileri bazından ele alan Sarışık vd.,'nin (2006: 33) çalışmasında ise otellerin işletmelerinin etik kodları benimsediklerini ve buna uygun faaliyetlerde bulunulduğunu ifade etmişlerdir.

Sosyal sorumluluk ölçeğinin ekonomik sorumluluk alt boyutuna genel olarak olumlu görüş belirtildiği, en olumlu görüşün ise malzeme ve enerji kullanımı azaltıcı uygulamalarda bulunulduğuna yönelik olduğu tespit edilmiştir. İşletmelerin bu şekilde uygulamalarda bulunması ekonomik açıdan işletmeye fayda sağladığı gibi çevreye de faydalı uygulamalar olmasından dolayı toplum ve tüketiciler gözünde de işletmeyi avantajlı duruma getirebilmektedir. Türker ve Uçar'ın (2013: 170) yapmış olduğu çalışmada da benzer sonuçlara ulaşılırken, Mirzayeva vd.,'nin (2016: 27) dört ve beş yıldızlı otellerde yapmış olduğu çalışmada ise sosyal sorumluluk projelerinde en az sıklıkla karşılanan ölçütün ekonomik sorumluluklar olduğu tespit edilmiştir.

Örgütsel bağlılık ölçeğinin duygusal bağlllık alt boyutunda çalışanların işletmelerine karşı güçlü bir aidiyet ve duygusal bağ hissettiklerine yönelik oldukça olumlu görüşler bildirdikleri tespit edilmiştir. Literatürde Tayfun vd., (2010: 12); Aruştei, (2013: 510); Hsu ve Tsai, (2014: 3); Oral, (2015: 85); Kumar ve Kumar, (2016: 29) tarafından yapılan araştırmalarda benzer sonuçlar elde edildiği görülmüştür. Çalışanların işletmelerine duygusal bağlılığının yüksek olması genel olarak işletmeler tarafından tercih edilendir. Çünkü duygusal bağlılığı yüksek olan çalışanlar işletmenin amaç ve değerlerini benimseyerek daha fazla emek harcamaya istekli olacaktır. Araştırma sonucunda çalışanların bu şekilde olumlu katılım göstermelerinin turizm sektörü içerisinde oldukça bilinen uluslararası zincir otellerde çalışmalarından ve sunulan hakların avantajlı olmasından kaynaklandığı söylenebilir.

Örgütsel bağlılık ölçeğinin devam bağlılığı alt boyutunda çalışanların mecburiyet dolayısı ile mevcut işlerinde çalıştıklarına ve işten ayrılmanın şu an için oldukça zor olduğuna yönelik oldukça olumlu görüş bildirdikleri tespit edilmiştir. Bu durumun çalışanların temel ihtiyaçlarını karşılamak için çalışmak zorunda olmasından ve uzun süredir çalıştıkları işlerinden kendi istekleri doğrultusunda ayrılmaları durumunda tazminat vb. haklarından vazgeçmek zorunda kalmak istememelerinden kaynaklandığı söylenebilir. Literatür incelendiğinde Özutku'nun (2008: 89) farklı bir sektörde yaptığı araştırmada da benzer sonuçlara ulaşılmıştır. Ancak turizm sektöründe Yalçın ve İplik, (2005: 406); Uzun ve Yiğit, (2011: 195); Salha vd., (2016: 10); Gürsel ve Eröz, (2017: 124) tarafından yapılan çalışmalarda çalışanların devam bağlılığı alt boyutuna ilişkin görüşleri görece olumsuz olarak tespit edilmiştir.

Örgütsel bağlllık ölçeğinin normatif bağlllık alt boyutunda çalışanların işletmelerine karşı güçlü bir sadakat hissettiklerine ve kendilerini borçlu hissettiklerine yönelik oldukça olumlu görüşler bildirdikleri tespit edilmiştir. Literatürde Aydın, (2016: 60); Uslu, (2018: 61); Bibican, (2019: 54); Tekeler, (2019: 98) tarafından yapılan araştırmalarda da benzer sonuçlar elde edildiği görülmüştür. Katılımcıların bu boyuttaki ifadelere verdikleri cevaplara genel olarak bakıldığında işletmelerine karşı ahlaki bir yükümlülük hissettikleri ancak kendi menfaatleri için daha faydalı bir fırsatla karşılaşmaları durumunda işten ayrılabilecekleri söylenebilir.

Katılımcların sosyal sorumluluk uygulamalarına yönelik görüşleri ile örgütsel bağlllık düzeyleri cinsiyete göre karşılaştıııldığında kadın katılımcıların sosyal sorumluluk uygulamalarına yönelik görüşlerinin erkeklere göre daha olumlu olduğu tespit edilmiştir. Bu durumun kadınların erkeklere göre sorumluluk bilincinin daha yüksek olmasından kaynaklandığı 
söylenebilir. Literatürde farklı sonuçlar elde edilen çalışmaların olduğu da görülmekle birlikte; Özdemir, (2007: 129); Kaya, (2008: 104); Çalışkan, (2010: 74); Serinikli, (2016: 463), Kim ve Kim; (2016: 9); Uslu, (2018: 62) tarafından gerçekleştirilen bazı çalışmalarda sosyal sorumluluk uygulamalarına yönelik görüşlerin cinsiyete göre anlamlı bir farklılık göstermediği tespit edilmiştir. Diğer taraftan ise erkeklerin örgütsel bağlllık düzeylerinin kadınlara göre daha yüksek olduğu tespit edilmiştir. Bu durumun erkeklerin toplumsal konumu sebebi ile çalışma zorunluluğu olmasından, kadınların ise evlendikten ve çocuk sahibi olduktan sonra kariyerlerini askıya almalarından kaynaklandığı söylenebilir. Literatürde cinsiyete göre örgütsel bağlllık görüşlerinde farklılık olup olmadığına dair bir netlik olmamakla birlikte; İleri vd., (2014: 91); Bhat, (2017: 67); Tekeler, (2019: 101) tarafından gerçekleştirilen bazı çalışmalarda cinsiyete göre anlamlı bir farklılık olduğu tespit edilmiştir. Ellemers vd., (2004); Kennedy ve Anderson, (2005); Yalçın ve İplik, (2005: 407); Boylu vd., (2007: 65); Serinikli, (2016: 463); Akmaz ve Erbaşı, (2017: 141) tarafından yapılan çalışmalarda ise cinsiyete göre anlamlı bir farklılık olmadığı tespit edilmiştir.

Katılımcıların sosyal sorumluluk uygulamalarına yönelik görüşleri ile örgütsel bağlılık düzeyleri medeni duruma göre karşılaştırıldığında bekar katılımcıların sosyal sorumluluk uygulamalarına yönelik görüşlerinin evlilere göre daha olumlu olduğu tespit edilmiştir. Bu durumun bekar katılımcıların evliler gibi eş, çocuk vb. sorumluluklarının olmamasından kaynaklandığı söylenebilir. Literatürde Türker ve Uçar'ın (2013: 172) çalışmasında da benzer sonuç bulunmasına rağmen genel olarak yapılan çalışmalarda Bayraktaroğlu vd., (2014: 114); Koçoğlu ve Aksoy, (2017: 105) anlamlı bir ilişki bulunmamaktadır. Diğer taraftan ise evli katılımcıların örgütsel bağlllık düzeylerinin bekar katılımcılara göre daha yüksek olduğu tespit edilmiştir. Bu durumun ise evlilerin hayatlarını devam ettirebilmeleri için çalışmak zorunda olmasından ve mevcut işini kaybetmesi durumunda ortaya çıabilecek zorluklarla uğraşmak istememesinden kaynaklandığı söylenebilir.

Katılımcıların sosyal sorumluluk uygulamalarına yönelik görüşleri ile örgütsel bağlılık düzeyleri yaş gruplarına göre karşılaştırıldığında $26-33$ ve $18-25$ yaş aralığındaki katılımcıların sosyal sorumluluk uygulamalarına yönelik görüşlerinin daha olumlu olduğu tespit edilmiştir. Literatürde farklı sonuçlar elde edilen çalışmaların olduğu da görülmekle birlikte; Kaya, (2008: 104); Serinikli, (2016: 464); Boğan, (2015: 80); Karabekiroğlu, (2016: 89); Khodayari, (2017: 66) tarafından gerçekleştirilen bazı çalışmalarda sosyal sorumluluk uygulamalarına yönelik görüşlerin yaş gruplarına göre anlamlı bir farklılık gösterdiği tespit edilmiştir. Diğer taraftan ise 42 yaş ve üzeri çalışanların örgütsel bağlılık düzeylerinin diğer yaş gruplarına göre oldukça yüksek olduğu tespit edilmiştir. Bu durumun ise bu yaştan sonra çalışanların işlerini kaybetmesi durumunda iş bulamayacağı endişesinden kaynaklandığı söylenebilir. Literatürde bu durumu destekleyen Angle ve Perry, (1981); Hunt vd., (1985); Pierce ve Dunham, (1987); Morrow ve McElroy, (1987); Cohen, (1993); İleri vd., (2014: 91) tarafından gerçekleştirilen çalışmalarda yaş grubuna göre anlamlı bir farklılık olduğu tespit edilmiştir.

Katılımcıların sosyal sorumluluk uygulamalarına yönelik görüşleri ile örgütsel bağlılık düzeyleri eğitim durumlarına göre karşılaştırıldığında lise ve altı, lisans ve lisanüstü düzeyinde eğitim alan katılımcıların sosyal sorumluluk uygulamalarına yönelik görüşlerinin daha olumlu olduğu tespit edilmiştir. Bu durumun eğitim düzeyi arttıkça sosyal sorumluluk bilincinin de artmasından kaynaklandığı söylenebilir. Literatürde Kaya, (2008: 104); Çalışkan, (2010: 77); Türker ve Uçar, (2013: 174); Karabekiroğlu, (2016: 90); Khodayari, (2017: 70) tarafından gerçekleştirilen çalışmalarda da sosyal sorumluluk uygulamalarına yönelik görüşlerin eğitim durumlarına göre anlamlı bir farklılık gösterdiği tespit edilmiştir. Serhat, (2008: 114); Bayraktaroğlu vd., (2014: 114); Boğan, (2015: 86); Serinikli, (2016: 465) tarafından yapılan bazı çalışmalarda ise eğitim durumuna göre anlamlı bir farklılık olmadığı tespit edilmiştir. Diğer taraftan ise lise ve altı ile lisansüstü 
düzeyde eğitim alan çalışanların örgütsel bağlllık düzeylerinin oldukça yüksek olduğu tespit edilmiştir. Bu durumun lise ve altı düzeyde eğitim alan çalışanların işlerini kaybetmesi durumunda iş bulamayacağı endişesinden kaynaklandığı söylenebilir. Literatürde bu durumu destekleyen Yalçın ve İplik, (2005: 407); Serhat, (2008: 115); Aruştei, (2013: 511); Öneği, (2014: 70); Bakırcı, (2016: 80); Bhat, (2017: 67) tarafından gerçekleştirilen çalışmalarda eğitim durumuna göre anlamlı bir farklılık olduğu tespit edilmiştir. Mathiue ve Zajac, (1990): Karabekiroğlu, (2016: 90); Akmaz ve Erbaşı, (2017: 141); Tekeler, (2019: 102) tarafından yapılan çalışmalarda ise; örgütsel bağlılık düzeylerinde eğitim durumuna göre anlamlı bir farklılık olmadığı tespit edilmiştir.

Katılımcıların sosyal sorumluluk uygulamalarına yönelik görüşleri ile örgütsel bağlllık düzeyleri çalıştıkları departmana göre karşılaştıııldığında satış ve pazarlama ile insan kaynakları departmanında çalışan katılımcıların sosyal sorumluluk uygulamalarına yönelik görüşlerinin daha olumlu olduğu tespit edilmiştir. Çalışanların departmanları ve yaptıkları iş nedeni ile sosyal sorumluluk uygulamalarında daha aktif rol almalarından kaynaklandığı söylenebilir. Diğer taraftan ise kat hizmetleri ve ön büro departmanında çalışanların örgütsel bağlılık ve iş performans düzeylerinin oldukça yüksek olduğu tespit edilmiştir. Kat hizmetleri ve ön büro departmanlarında çalışanların pozisyonlarından memnun olmalarından kaynaklandığı söylenebilir. Literatürde bu durumu destekleyen Yalçın ve İplik, (2005: 407); Serhat, (2008: 116); Ertan, (2008: 134); Tükeltürk vd., (2012: 103); Öneği, (2014: 79); Bakırcı, (2016: 85); Bhat, (2017: 69) tarafından yapılan çalışmalarda çalışılan departmana göre anlamlı bir farklılık olduğu tespit edilmiştir.

Katılımcıların sosyal sorumluluk uygulamalarına yönelik görüşleri ile örgütsel bağlılık düzeyleri gelir düzeylerine göre karşılaştırıldığında 3000 TL ve altında olan katılımcıların sosyal sorumluluk uygulamalarına yönelik görüşlerinin, örgütsel bağlılık ve iş performans düzeylerinin daha olumlu olduğu tespit edilmiştir. Bu durumdan çalışanların manevi değerleri maddi değerlerle ölçmediğini, sadece temel ihtiyaçlarını karşılayabilecek kadar gelir düzeyine sahip olsa bile işletmesinin sosyal sorumluluk uygulamalarında bulunarak paydaşlarına fayda sağlıyor olmasının onların oteline bağlı ve performansının yüksek olmasını sağladığı anlaşılmaktadır. Literatürde bu durumu destekleyen Yalçın ve İplik, (2005: 408); Çalışkan, (2010: 78); Tükeltürk vd., (2012: 103); Tekeler, (2019: 105) tarafından gerçekleştirilen çalışmalarda gelir düzeyine göre anlamlı bir farklılık olduğu tespit edilmiştir.

Araştırmanın temel konusu çerçevesinde sosyal sorumluluk uygulamalarına yönelik görüşler, örgütsel bağlllık düzeyleri arasındaki ilişkiye bakıldığında sosyal sorumluluk uygulamalarının genel örgütsel bağlılık ile ilişkili olmadığı ancak duygusal bağlılık ve devam bağlılığı alt boyutu ile pozitif yönlü, düşük düzeyli ve anlamlı bir ilişkisi olduğu tespit edilmiştir. Buna göre kurumların sosyal sorumluluk uygulamalarının çalışanların duygusal ve devam bağlılıkları üzerinde olumlu yönde etki yarattığı ve sosyal sorumluluk algılamaları arttıkça işletmeye olan bağlılıklarının da artacağı anlaşılmaktadır.

Araştırmanın bulguları sonucunda elde edilen bilgiler neticesinde otel ve tüm turizm işletmelerine yönelik önerileri aşağıdaki gibi özetlemek mümkündür. Geçmişten günümüze önemini koruyan sosyal sorumluluk boyutlarının her biri ile ilgili gerekli çalışmaların yapılması çalışanların örgüte olan bağlılıklarını ve performansını arttırabilecektir. Bu bağlamda;

- Yaş aralığı bulguları ele alındığında, 18 - 25 yaş aralığındaki çalışanların sosyal sorumluluk algılamaları ile örgütsel bağlılık düzeylerinin yüksek olduğu saptanmıştır. Hizmet sektöründe yer alan turizm işletmelerinin yoğun emek gücü gerektirmesinden dolayı başlangıçta daha genç çalışanların kadroda tercih edilmesi ve başarılı sosyal sorumluluk uygulamaları ile işletmeye olan bağlılıklarının ve yüksek performanslarının devamlılığı sağlanmalıdır. Yaş 
ortalaması daha yüksek olan çalışanlarını ise aynı duyarlılık seviyesine taşımak için bilinçlendirilmelidirler.

- Çalışanların eğitim durumlarına göre sosyal sorumluluk algılamaları ile örgütsel bağlılık düzeyleri değişiklik göstermekte ve eğitim düzeyleri arttıkça algı, bağlllık düzeyleri de artmaktadır. Bu bağlamda işletmeler eğitim düzeyi yüksek kalifiye çalışanları kadrolarına dahil etmeli ve bağlılıklarını sağlamalıdırlar. Eğitim düzeyi daha düşük olan çalışanlarını ise aynı duyarlılık seviyesine taşımak için bilinçlendirmelidirler.

- İşletmelerin önbüro, satış pazarlama ve kat hizmetleri bölümdeki çalışanların sosyal sorumluluk algılamaları ile örgütsel bağlllık düzeylerinin yüksek olduğu saptanmıştır. Bu nedenle diğer bölümlerde çalışanlarda da aynı hassasiyeti yaratabilmek için bu bölümlerde çalışan kalifiye elemanlara yönelik daha fazla sosyal sorumluluk uygulamalarında bulunulmalıdır.

- Genel olarak işletmeler tarafından çalışanlarının menfaatini gözeten, işletmeye olan bağlılıklarını ve performanslarının arttırılmasını sağlayıcı sosyal sorumluluk aktivitelerinde bulunulmalıdır.

- Çalışanların kendilerinin topluma ve çevreye faydalı olduğunu düşünerek önemli olduklarını hissetmelerini sağlamak amacıyla sosyal sorumluluk uygulamalarında çalışanlara da aktif roller verilmelidir.

- $\quad$ İşletmeler, özellikle çalışanların aktif olarak katıldıkları olmak üzere yapmış olduğu tüm sosyal sorumluluk faaliyetleri ile ilgili çalışanlarını bilgilendirmelidirler. Sosyal sorumluluk görevlerini yerine getiren bir işletmede çalıştığının bilincinde olan çalışanlar, işletmelerinin hedef ve değerlerini benimseyerek işletmesine daha da bağlanacak ve elinden geleni yapmak üzere daha çok performans sergileyecektirler.

Sonuç olarak turizm işletmelerinin asıl amacı misafirlerinin en unutulmaz tatil deneyimini yaşamasını sağlayacak kaliteli hizmeti sunmaktır. Bu amacını yerine getirmesinde en önemli görev çalışanlarına düşmektedir. Bu sebeple işletmelerin profesyonel ve kalifiye çalışanlar tarafından tercih edilmesine katkı sağlayacak sosyal sorumluluk uygulamalarında bulunması ve bunu bir işletme politikası haline getirmesi oldukça önemlidir. İşletmelerin bu tarz uygulamaları çalışanların örgütsel bağlılıklarını ve iş performanslarını pozitif yönde etkileyecektir.

$\mathrm{Bu}$ araştırma uluslararası zincir olan ve İstanbul'da faaliyet gösteren beş yıldızlı otel işletmeleri çalışanları üzerinde yapıldığından analiz sonuçlarını genelleyebilmek adına benzer araştırmaların yerel işletmelerde, daha büyük örneklem sayıları ile farklı şehirlerde ve ölçeklerle de yapilması gerekmektedir.

\section{KAYNAKÇA}

Akmaz, A. ve Erbaşı, A. (2017). Psikolojik Kontrat ile Örgütsel Bağlllık ve Örgütsel Güven İlişkisi: Mersin İlindeki 4 ve 5 Yıldızlı Otel İşletmelerinde Bir Uygulama, AİBU Sosyal Bilimler Enstitüsü Dergisi, 17(4): 125-154.

Akova, O. ve Bayhan, İ. (2015). Örgütsel Bağlılık ve Rekreasyonel İmkanlar Arasındaki İlişki: Antalya'da Konaklama İşletmelerinde Çalışanların Üzerinde Bir Araştırma, Uluslararası Sosyal Araştırmalar Dergisi, 8(38): 789-805.

Allen, N. J. and Meyer, J. P. (1990). The Measurement and Antecedents of Affective, Continuance and Normative Commitment to The Organization, Journal of Occupational Psychology, 63, 1-18.

Altınöz, M. (2018). Yetenek Yönetiminin Algılanması Üzerine Karşılaştırmalı Bir Araştırma. Selçuk Üniversitesi Sosyal Bilimler Enstitüsü Dergisi, 39, 82-95. 
Angle, H. and Perry, J. L. (1981). An Empirical Assessment of Organizational Commitment and Effectiveness, Administrative Science Quarterly, 26, 1-14.

Arbak, Y. ve Kesken, J. (2005). Örgütsel Bağlllık, Sağlık Hizmetlerinde Sürekli Gelişim İçin Davranışsal Bir Yaklaşım, İzmir: Dokuz Eylül Üniversitesi Yayınları.

Aruştei, C. C. (2013). Employees' Organizational Commitment Challenges - a Hotel Industry Perspective, Management Dynamics in the Knowledge Economy, 3, 497-519.

Ata, H. ve Ataman, G. (2020). Kurumsal Sosyal Sorumluluk, Algılanan Dışşsal Prestij ve Örgütsel Bağll1ık: Sosyal Kimlik Kuramı Çerçevesinde Bir Araştırma, Yönetim Bilimleri Dergisi /Journal of Administrative Sciences, 18 (36): 255-273.

Ateşoğlu, İ. ve Türker, A. (2010). Konaklama İşletmelerinin Sosyal Sorumluluk Faaliyetlerine Yaklaşımı: Muğla İli Örneği, Süleyman Demirel Üniversitesi İktisadi ve İdari Bilimler Fakültesi Dergisi, 5(3): 207-226.

Avcı, N. ve Küçükusta, D. (2009). Konaklama İşletmelerinde Örgütsel Öğrenme, Örgütsel Bağlllık ve İşten Ayrılma Eğilimi Arasındaki İlişki, Anatolia: Turizm Araştırmaları Dergisi, 20(1): 33-44.

Aydın, M. (2016). Örgütsel Bă̆lllık ve Örgütsel Sinizm Illişkisi: Güneydoğu Anadolu Bölgesi'nde Faaliyet Gösteren Dört ve Beş Yıldızlı Otel İşletmeleri Çalışanlarına Yönelik Bir Araştırma, Yayınlanmamış Yüksek Lisans Tezi, Mersin Üniversitesi, Mersin.

Bakırcı, B. (2016). Konaklama İşletmelerinde Çalışanların Örgütsel Bağhllı̆̆ının İşgören Performansı Üzerindeki Etkileri, Yayınlanmamış Yüksek Lisans Tezi, Muğla Sıtkı Koçman Üniversitesi, Muğla.

Balay, R. (2000). Yönetici ve Öğretmenlerde Örgütsel Bağlllık. Ankara: Nobel Yayıncılık.

Bayrak, S. (2001). İş Ahlakı ve Sosyal Sorumluluk, (1.Baskl), İstanbul: Beta Basım.

Bayraktaroğlu, S., Yılmaz, S. E. ve Can, M. (2014). Kurumsal Sosyal Sorumluluk Algısının Örgütsel Bağlllığa Etkisini Belirlemeye Yönelik Bir Araştırma, Siyaset Ekonomik ve Yönetim Araştırmaları Dergisi, 2 (3): 99-122.

Bayram, L. (2005). Yönetimde Yeni Bir Paradigma: Örgütsel Bağlllık. Sayıştay Dergisi, 59: 125-139.

Bhat, R. K. (2017). Job Satisfaction \& Organizational Commitment in the Hotel Industry. Master Thesis, Joseph School of Business Studies Department of Business Admistration, India.

Bibican, Ç. (2019). Ankara'da Bulunan Beş Yıldızlı Otel İşletmelerinde Hizmet Verme Yatkınlı̆̆ının Örgütsel Bağlllık ve İş Tatmini İlişkisi, Yayınlanmamış Yüksek Lisans Tezi, Atılım Üniversitesi, Ankara.

Bulşu, Ç. ve Gümüş, M. (2018). Farklılıkların Yönetimi ve Örgütsel Bağlllı̆̆ın İşten Ayrılma Niyetine Etkisi, Journal of Tourism and Gastronomy Studies, 6(4): 322-344.

Boğan, E. (2015). Çalışanlar Tarafından Algılanan Kurumsal Sosyal Sorumluluk Faaliyetlerinin Örgüte Güven Üzerindeki Etkisi: Alanya'daki Dört ve Beş Yıldızh Otellerde Bir Uygulama, Yayınlanmamış Yüksek Lisans Tezi, Akdeniz Üniversitesi, Antalya.

Boğan, E. (2020). Otel Çalışanlarının Kurumsal Sosyal Sorumluluk Algısının İşveren Çekiciliği ve Duygusal Bağlılık Üzerine Etkisi: Kurumsal İtibarın Aracılık Rolü, Alanya Akademik Bakı̧̧, 4(2): 381-398.

Boylu, Y., Pelit, E. ve Güçer, E. (2007). Akademisyenlerin Örgütsel Bağlllık Düzeyleri Üzerine Bir Araştırma, Finans Politik ve Ekonomik Yorumlar Dergisi, 44 (511): 55-74.

Cappelli, P. (2000). Managing Without Commitment, Organizational Dynamics, 28(4): 11-24. 
Carroll, B. A. (1991). The Pyramid of Corporate Social Responsibility: Toward the Moral Management of Organizational Stakeholders, Business Horizons, 28(3): 40-52.

Cohen, A. (1993). Age and Tenue in Relation to Organizational Commitment: A Meta-Analysis, Journal of Organizational Behavior, 14(2): 143-159.

Çalışkan, O. (2010). Kurumsal Sosyal Sorumluluk Algılama Boyutunun Personelin İş Tatminine ve İşte Kalma Niyetine Etkisi: Antalya Bölgesinde Yer Alan Beş Yıldızh Konaklama İşletmelerinde Çalışanlar Üzerinde Bir Araştırma, Yayınlanmamış Yüksek Lisans Tezi, Selçuk Üniversitesi, Konya.

Çalışkan, O. ve Ünüsan, Ç. (2011). Otel Çalışanlarının Kurumsal Sosyal Sorumluluk Algısının İş Tatmini ve İşte Kalma Niyetine Etkisi, Turizm Araştırmaları Dergisi, 22 (2): 154-166.

Çelebi, M.A. (2009). Örgütsel Bă̆lılığın Sınıflandırılmasında Bir Araç Olarak Personel Güçlendirme, Yayınlanmamış Yüksek Lisans Tezi, Karamanoğlu Mehmetbey Üniversitesi, Karaman.

Çetin, M. Ö. (2004). Örgüt Kültürü ve Örgütsel Bă̆lllık. Ankara: Nobel Yayın Dağıtım.

Çolakoğlu, O. E. (2005). Sosyal Sorumluluk ve Etik, (Editör) Demir, C.: Konaklama İşletmelerinde İnsan Kaynakları Yönetimi: Ilkeler ve Uygulamalar içinde (ss. 359-381). Ankara: Nobel Yayın Dağıtım.

Çuhadar, M. ve Gencer, Z. (2016). Konaklama İşletmelerinde Çalışan İşgörenlerin Aşırı İş Yükü ve Örgütsel Bağlllık Alg1ları: Side ve Belek Örneği, Süleyman Demirel Üniversitesi İktisadi ve İdari Bilimler Fakültesi Dergisi, 21(4): 1323-1346.

Davras, Ö. ve Gülmez, M. (2013). Otel İşletmelerinde Çalışan Memnuniyetine Etki Eden Faktörler: Kemer-Lara-Belek-Side-Alanya Bölgelerinde Bir Çalışma, Anatolia: Turizm Araştırmaları Dergisi, 24 (2): 167-184.

Demirel, Y. (2009). Örgütsel Bağlılık ve Üretkenlik Karşıtı Davranışlar Arasındaki İlişkiye Kavramsal Yaklaşım, İstanbul Ticaret Üniversitesi Sosyal Bilimler Dergisi, 8 (15): 115-132.

Ellemers, N., Van Den Heuvei, H., Gilder, D., Maass, A. and Bonvini, A. (2004). The Underrepresenitation of Women in Science: Differential Commitment or The Queen Bee Syndrome, British Journal of Social Psychology, 43, 315-338.

Erdoğdu, F. B. ve Sökmen, A. (2019). Örgütsel Bağlılık ile İş Tatmini ve İşten Ayrılma Niyeti İlişkisinde Örgütsel Vatandaşlık Davranışının Aracılık Rolü, Journal of Tourism and Gastronomy Studies, 7 (1): 244-264.

Erkol Bayram, G. (2018). Etik Değerler ve Örgütsel Bağlllık İlişkisi Üzerine Turizm İşletmeleri Örneğinde Bir Araştırma, Güncel Turizm Araştırmaları Dergisi, 2(2): 228-259.

Ertan, H. (2008). Örgütsel Bă̆gllık, İş Motivasyonu, İş Performansı Arasındaki İlişki: Antalya'da Beş Yıldızlı Otel İşletmelerinde Bir İnceleme. Yayınlanmamış Doktora Tezi, Afyonkarahisar Kocatepe Üniversitesi, Afyonkarahisar.

Gül, H. (2002). Örgütsel Bağlılık Yaklaşımlarının Mukayesesi ve Değerlendirilmesi, Ege Akademik Bakış Dergisi, 2 (1): 37-56.

Gürsel, Ü. ve Eröz, S. S. (2017). Örgütsel Bağlılık ve Yenilik Yönetimi İlişkisi: Mutfak Personeli Üzerine Bir Araştırma, International Journal of Academic Value Studies, 13(13): 109-132.

Holme, R. and Watts, P. (2000). Corporate Social Responsibility: Making Good Business Sense, Geneva: WBCSD, World Business Council for Sustainable Development.

Hsu, M. S. and Tsai, Y. Y. (2014). Career Satisfaction and Organizational Commitment among Hotel Employees in Taiwan, Journal of Hotel \& Business Management, 3(1): 1-4. 
Hunt, S., Chonko, L. B. and Wood, V. R. (1985). Organizational Commitment and Marketing, Journal of Marketing, 49 (Winter): 112-126.

Işık, U. ve Yasım, Y. K. (2017). Otel Çalışanlarının Psikolojik Güçlendirme ile Örgütsel Bağlılıkları Arasındaki İlişki, Hitit Üniversitesi Sosyal Bilimler Enstitüsü Dergisi, 2: 1581-1594

İleri, H., Karaman, A. ve Engiz, G. (2014). Çalışanlarda Kariyer Tatmini ve Örgütsel Bağlllık İlişkisi, Selçuk Üniversitesi Sosyal Bilimler Meslek Yüksekokulu Dergisi, 12(1-2): 78-96.

Karabekiroğlu, A. (2016). Kurumsal Sosyal Sorumluluk Çalışmaları Yapılan Kurumlarda Çalışan Memnuniyeti ve Çalışan Bağlılığı, Yayınlanmamış Yüksek Lisans Tezi, Bahçeşehir Üniversitesi, İstanbul.

Kaya, H. (2008). Demografik Özelliklerin Kurumsal Sosyal Sorumluluk Algılaması Üzerindeki Rolü: Bandırma Yerelinde Bir Araştırma, Balıkesir Üniversitesi Sosyal Bilimler Enstitüsü Dergisi, 11(20): 96-110.

Kennedy, J. R. and Anderson, R. D. (2005). Subordinate-Manager Ender Combination and Perceived Leadership Style Influence on Motions, Self-Esteem and Organizational Commitment, Journal of Business Research, 58: 115-125.

Kesen, M. ve Sipahi, G. A. (2016). Örgütsel İmajın Örgütsel Bağlllık ve İşgören Performansına Etkisi, Uluslararası Sosyal Araştırmalar Dergisi, 9(43): 1927-1934.

Khodayari, M. (2017). Kurumsal Sosyal Sorumluluğun Örgütsel Bağlllık Üzerine Etkisi: Ankara İlinde Bir Uygulama, Yayınlanmamış Yüksek Lisans Tezi, Gazi Üniversitesi, Ankara.

Kılıç, S. (2016). Cronbach'ın Alfa Güvenirlik Katsayısı, Journal of Mood Disorders, 6 (1): 47-48.

Kim, S. B. and Kim, D. Y. (2016). The Influence of Corporate Social Responsibility, Ability, Reputation, and Transparency on Hotel Customer Loyalty in the U.S.: A Gender-Based Approach. Springer Plus, 5 (1537): 1-13.

Koçoğlu, C. M. ve Aksoy, R. (2017). Demografik Değişkenlerin Kurumsal Sosyal Sorumluluk Algısı Üzerindeki Etkileri Üzerine Bir Araştırma, Uluslararası Yönetim İktisat ve Isşletme Dergisi, 13(1): 89-116.

Kumar, S. and Kumar, M. (2016). Job Satisfaction and Organizational Commitment in Hospitality Industry - An Empirical Study, Amity Research Journal of Tourism, Aviation and Hospitality, 1(2): 25-32.

Lee, Y. K., Kim, Y. S., Lee, K. H. and Li, D. (2012). The Impact of CSR on Relationship Quality and Relationship Outcomes: A Perspective of Service Employees, International Journal of Hospitality Management, 31: 745-756.

Liou, S. R. (2008). An Analysis of the Concept of Organizational Commitment, Nursing Forum, 43(3): 116-125.

Maignan, I. and Ferrell, O. C. (2001). Corporate Citizenship as a Marketing Instrument - Concepts, Evidence and Research Directions, European Journal of Marketing, 35(3): 457-484.

Mathieu, J. E. and Zajac, D. M. (1990). A Review and Meta-Analysis of The Antecedents, Correlates and Consequences of Organizational Commitment, Psychological Bulletin, 108(2): 171194.

Meyer, J. and Allen, N. (1997). Commitment in the workplace: Theory, research, and application. Thousand Oaks, CA: Sage Publications. 
Minareci, Y. (2007). Turizm İşletmelerinde Kurumsallaşma ve Sosyal Sorumluluk: Otel Işsletmelerinde Bir Uygulama, Yayınlanmamış Yüksek Lisans Tezi, Dokuz Eylül Üniversitesi, İzmir.

Mirzayeva, G., Oruç, M. C., Gök, D. K. ve Batman, O. (2016). Turizm İşletmelerinde Sosyal Sorumluluk Yaklaşımları: 4 ve 5 Yıldızlı Konaklama İşletmeleri Üzerine Bir Araştırma, Türk Bilim Araştırma Vakfı Dergisi, 9 (4): 23-30.

Mohr, L. A., Webb, D. J. and Harris, K. E. (2001). Do Consumers Expect Companies to be Socially Responsible? The Impact of Corporate Social Responsibility on Buying Behavior, The Journal of Consumer Affairs, 35(1): 45-72.

Morrow, P. C. (1983). Concept Redundancy in Organizational Research: The Case of Work Commitment, Academy of Management Review, 8 (3): 486-500.

Morrow, P. C. and Mc Elroy, J. C. (1987). Work Commitment and Job Satisfaction over Three Career Stages, Journal of Vocational Behavior, 30, 486-500.

Mowday, R.T., Porter, L.W. and Steers, R.M. (1982). Employee Organization Linkages; The Psychology of Commitment, Absenteeism and Turnover, New York: Academic Press.

Naktiyok, S. ve İşcan, Ö.F. (2014). Çalışanların Örgüte Olan Bağlllıklarında Bir Öncül Olarak Örgütsel Öğrenmenin Rolü, Kafkas Üniversitesi İktisadi ve İdari Bilimler Fakültesi Dergisi, 5 (7): 1937.

Newsom, D., Turk, J. S. and Kruckeberg, D. (2000). This is PR: The Realities of Public Relations. (7th ed.). USA: Wadsworth Inc.

Oral, H. (2015). Otel İşletmelerinde İş Koşullarının Çalışanların Örgütsel Bağlılıkları Üzerine Etkisi, Yayınlanmamış Yüksek Lisans Tezi, Balıkesir Üniversitesi, Balıkesir.

Öneği, M. (2014). Otel İşletmelerinde Çalışan İşgörelerin Örgütsel Bağhllık Düzeyinin İş Tatmini ve Çalışma Performansına Etkisi, Yayınlanmamış Yüksek Lisans Tezi, Gazi Üniversitesi, Ankara.

Örücü, E. ve Kışlalıoğlu, R. S. (2014). Örgütsel Bağlılık Üzerine Bir Alan Çalışması, Uluslararası Yönetim İktisat ve İsletme Dergisi, 10 (22): 45-66.

Özdamar, K. (2001). Spss ile Biyoistatistik. (4.Basım). Eskişehir: Kaan Kitabevi.

Özdemir, E. ve Akpınar, A. T. (2002). Konaklama İşletmelerinde İnsan Kaynakları Yönetimi Çerçevesinde Alanya'daki Otel ve Tatil Köylerinde İnsan Kaynakları Profili, Kocaeli Üniversitesi Sosyal Bilimler Enstitüsü Dergisi, 3 (2): 85-105.

Özdemir, H. Ö. (2007). Çalışanların Kurumsal Sosyal Sorumluluk Algılamalarının Örgütsel Özdeşleşme, Örgütsel Bağlılık ve İş Tatminine Etkisi: Opet Çalışanlarına Yönelik Uygulama, Yayınlanmamış Doktora Tezi, Marmara Üniversitesi, İstanbul.

Özutku, H. (2008). Örgüte Duygusal, Devamlılık ve Normatif Bağlılık ile İş Performansı Arasındaki İlişkinin İncelenmesi, İstanbul Üniversitesi İşletme Fakültesi Dergisi, 37(2): 76-81.

Pelit, E. ve Arslantürk, Y. (2011). Turizm İşletmelerinin İş Etiğine Yönelik Uygulamalarının Çalışma Yeri Tercihindeki Önemi: Turizm Öğrencileri Üzerinde Bir Araştırma, Süleyman Demirel Üniversitesi İktisadi ve İdari Bilimler Fakültesi Dergisi, 16(1): 163-184.

Pelit, E. ve Pekmezci, D. (2012). Turizm İşletmelerinde Sosyal Sorumluluk Alanları, (Editör) Ören,K., Eser, H. B. ve Akman, E.: Farklı Bakış Açılarıyla Sosyal Sorumluluk içinde (ss. 317-351) Ankara: Pelikan Yayıncılık Ltd. Şti.

Pierce, J.L. and Dunham, R. B. (1987). Organizational Commitment: Pre-Employment Propensity and Initial Work Experiences, Journal of Management, 13, 163-178. 
Rosin, H. and Korabik, K. (1995). Organizational Experiences and Propensity to Leave: A Multivariate Investigation of Men and Women Managers, Journal of Vocational Behavior, 46(1): 116.

Salha, H., Cinnioğlu, H. Yazıt, H. ve Yenişehirlioğlu, E. (2016). İşgörenlerin Örgütsel Sessizlik Düzeylerinin Örgütsel Bağlılıklarına Etkisi: Tekirdağ'daki Yiyecek İçecek İşletmeleri Üzerine Bir Araştırma, Balkan ve Yakın Doğu Sosyal Bilimler Dergisi, 02(03): 5-15.

Salha, H. ve Ulema Ş. (2020). Personel Güçlendirmenin Örgütsel Bağlllık Üzerine Etkisi: Yiyecek İçecek İşletmeleri Üzerine Bir Araştırma, Trakya Üniversitesi Sosyal Bilimler Dergisi, 22 (1): 439-451.

Sarışık, M., Akova, O. ve Çontu, M. (2006). Otel Yöneticilerinin Etik Politika ve Yöntemlere Yaklaşımları, Anatolia: Turizm Araştırmaları Dergisi, 17(1): 22-34.

Sekaran U. (2003). Research Methods for Business. New York (USA): John Wiley High Education Press.

Serhat, C. (2008). Otel İşletmelerinde Çalışanların Örgütsel Bağhllı̆̆ının İşören Performansı Üzerindeki Etkileri, Yayınlanmamış Yüksek Lisans Tezi, Adnan Menderes Üniversitesi, Aydın.

Serinikli, N. (2016). Demografik Özellikler Açısından Çalışanların Kurumsal Sosyal Sorumluluk Algıları, Balıesir Üniversitesi Sosyal Bilimler Enstitüsü Dergisi, 19(35): 455-473.

Serinikli, N. (2018). Çalışanların Kurumsal Sosyal Sorumluluk Algılarının Örgütsel Bağlılıkları ile İlişkisi, Pamukkale Üniversitesi Sosyal Bilimler Enstitüsü Dergisi, 31: 285-301.

Sheldon, O. (1923). The Philosophy of Management. Londra: Pitman Publisher. [Online] Open Library.https://archive.org/details/philosophyofmana00sheluoft/page/52/mode/1up?ref=ol\&vie $\mathrm{w}=$ theater $>$ [Erişim Tarihi: 10.03.2021].

Şahinoğlu, F. (2011). Kurumsal Sosyal Sorumluluk Faaliyetlerinin Çalışanların Örgütsel Bağlllıklarıyla Olan İlişkisine Yönelik Bir Uygulama, Yayınlanmamış Yüksek Lisans Tezi, Yıldız Teknik Üniversitesi, İstanbul.

Şimşek, B. (1999). Yöneticilerin Çalışanlarına Karşı Etik Sorumlulukları, Dokuz Eylül Üniversitesi Sosyal Bilimler Enstitüsü Dergisi, 1(3): 69-86.

Taşkın, E. ve Yeni, Z. (2016). İçsel Pazarlama Faaliyetlerinin Örgütsel Bağlllık Üzerindeki Etkisini Belirlemeye Yönelik Bir Araştırma, Kastamonu Üniversitesi İktisadi ve İdari Bilimler Fakültesi Dergisi, 11: $62-86$.

Tayfun, A., Palavar, K. ve Çöp, S. (2010). İşgörenlerin Eğitim ve Örgütsel Bağlllık Düzeyleri Arasındaki İlişki: Belek Bölgesindeki Beş Yıldızlı Otel İşletmelerinde Bir Araştırma, İşletme Araştırmaları Dergisi, 2(4): 3-18.

Tekeler, M. C. (2019). Konaklama İşletmelerinde Örgüt Kültürü ve Örgütsel Bă̆lllık Arasındaki İlişki: Kuşadası'ndaki Dört ve Beş Yıldızlı Otel İşletmeleri Örneği, Yayınlanmamış Yüksek Lisans Tezi, Adnan Menderes Üniversitesi, Aydın.

Tükeltürk, Ş. A., Perçin, N. Ş. ve Güzel, B. (2012). Psikolojik Kontrat İhlal Algısı ile Örgütsel Bağllık İlişkisi: Otel İşletmeleri Üzerine Bir Araştırma, Yönetim Bilimleri Dergisi, 10 (20): 93-110.

Türker, N. ve Uçar, M. (2013). Konaklama İşletmelerinin Sosyal Sorumlulukları, İşletme Araştırmaları Dergisi, 5 (3): 144-183.

Uslu, N. (2018). Otel İşletmelerinde Kurumsal İtibarın Çalışanların Örgütsel Bağhllı̆̆ına ve Çalışan Performansına Etkisi, Yayınlanmamış Yüksek Lisans Tezi, Eskişehir Osmangazi Üniversitesi, Eskişehir. 
Uzun, Ö. ve Yiğit, E. (2011). Örgütsel Stres ve Örgütsel Bağlllık İlişkisi Üzerine Orta Kademe Otel Yöneticileri Üzerinde Yapılan Bir Araştırma, Eskişehir Osmangazi Üniversitesi İ̈BF Dergisi, 6(1): 181-213.

Ünlüönen, K. ve Şahin, S. Z. (2011). Turizmde İstihdam, Elektronik Sosyal Bilimler Dergisi, 10 (37): $1-25$.

Windsor, D. (2001). The Future of Corporate Social Responsibility, The International Journal of Organizational Analysis, 9(3): 225-256.

Yalçın, A. ve İplik, F. N. (2005). Beş Yıldızlı Oteller Çalışanların Demografik Özellikleri ile Örgütsel Bağlllıkları Arasındaki İlişkiyi Belirlemeye Yönelik Bir Araştırma: Adana İli Örneği, Çukurova Üniversitesi Sosyal Bilimler Enstitüsü Dergisi, 14 (1): 395-412. 